\title{
Oxide Dispersion Strengthened Nickel Based Alloys via Spark Plasma Sintering
}

Somayeh Pasebani ${ }^{\mathrm{a}}$, Aniket K. Dutt ${ }^{\mathrm{b}}$, Jatuporn Burns ${ }^{\mathrm{c}}$, Indrajit Charit ${ }^{\mathrm{a}, 1}$ and Rajiv S. Mishra ${ }^{\mathrm{b}}$

${ }^{\text {a } U n i v e r s i t y ~ o f ~ I d a h o, ~ M o s c o w, ~ I D ~ 83844-3024, ~ U S A ~}$

${ }^{\mathrm{b}}$ University of North Texas, Denton, TX 76203, USA

${ }^{c}$ Boise State University, Center for Advanced Energy Studies, Idaho Falls, ID 83401, USA

Abstract

Oxide dispersion strengthened (ODS) nickel based alloys were developed via mechanical milling and spark plasma sintering (SPS) of Ni-20Cr powder with additional dispersion of $1.2 \mathrm{wt} \%$ $\mathrm{Y}_{2} \mathrm{O}_{3}$ powder. Furthermore, 5 wt. $\% \mathrm{Al}_{2} \mathrm{O}_{3}$ was added to $\mathrm{Ni}-20 \mathrm{Cr}-1.2 \mathrm{Y}_{2} \mathrm{O}_{3}$ to provide composite strengthening in the ODS alloy. The effects of milling times, sintering temperature, and sintering dwell time were investigated on both mechanical properties and microstructural evolution. A high number of annealing twins was observed in the sintered microstructure for all the milling times. However, longer milling time contributed to improved hardness and narrower twin width in the consolidated alloys. Higher sintering temperature led to higher fraction of recrystallized grains, improved density and hardness. Adding $1.2 \mathrm{wt} . \% \mathrm{Y}_{2} \mathrm{O}_{3}$ to $\mathrm{Ni}-20 \mathrm{Cr}$ matrix significantly reduced the grain size due to dispersion strengthening effect of $\mathrm{Y}_{2} \mathrm{O}_{3}$ particles in controlling the grain boundary mobility and recrystallization phenomena. The strengthening mechanisms at room temperature were quantified based on both experimental and analytical calculations with a good agreement. A high compression yield stress obtained at $800{ }^{\circ} \mathrm{C}$ for $\mathrm{Ni}-20 \mathrm{Cr}-1.2 \mathrm{Y}_{2} \mathrm{O}_{3}-5 \mathrm{Al}_{2} \mathrm{O}_{3}$ alloy was attributed to a combined effect of dispersion and composite strengthening.

Keywords: Ni-Cr based alloys; High energy ball milling; Spark plasma sintering; Dispersion strengthening; Composite strengthening

(C) 2015. This manuscript version is made available under the Elsevier user license http://www.elsevier.com/open-access/userlicense/1.0/

\footnotetext{
${ }^{1}$ Corresponding author. Tel. +1 208885 5964; Fax: +1 2088857462

E-mail address: icharit@uidaho.edu (I. Charit)
} 


\section{Introduction}

Increasing the operating temperatures in coal-fired power plants, gas turbine inlets, and other high temperature structural components in order to improve their efficiency and economy will require new materials with high mechanical and creep strength, oxidation and corrosion resistance. Nickel based alloys are promising candidates for such applications due to their excellent corrosion resistance at elevated temperatures [1-3].

While conventional nickel based alloys may not be very stable at high temperatures due to coarsening or dissolution of the second phase particles, nickel based oxide dispersion strengthened ODS alloys, reinforced by homogeneously dispersed nanoparticles (usually $\mathrm{Y}_{2} \mathrm{O}_{3}$ ), are quite stable during high temperature applications in excess of $1000{ }^{\circ} \mathrm{C}$ [4]. Homogeneous dispersion of nanometric stable oxide particles in the matrix of nickel based ODS alloys can act as effective barriers against dislocation motion [2, 5-7] and improve high temperature mechanical properties including creep strength [8]. The pinning effects of oxide nanoparticles depend on the mean particle separation (the mean distance between the particles) which is a direct result of the particle number density [1]. According to theoretical calculations and experiments, a combination of a mean particle separation of 100-250 nm for 10-20 nm yttria particles and grain aspect ratio of a minimum of 10 could be promising for high- temperature applications $[3,6]$.

In nickel based ODS powder containing both $\mathrm{Al}$ and $\mathrm{Y}_{2} \mathrm{O}_{3}$, different $\mathrm{Y}$-Al-O particles such as $\mathrm{Y}_{3} \mathrm{Al}_{5} \mathrm{O}_{12}, \mathrm{YAlO}_{3}$ (perovskite), $\mathrm{Y}_{4} \mathrm{Al}_{2} \mathrm{O}_{9}$ and $\mathrm{YAlO}_{3}$ (hexagonal) can be formed during consolidation [1]. Recently, it has been noted that adding some minor elements such as Ti and Hf can replace the Y-Al-O particles with Y-Ti-Hf-O particles. The effects of adding minor elements such as $\mathrm{Ti}, \mathrm{Mg}, \mathrm{Zr}, \mathrm{Ca}$ and $\mathrm{Hf}$ to $\mathrm{Ni}-0.5 \mathrm{Al}-1 \mathrm{Y}_{2} \mathrm{O}_{3}$ (wt.\%) was studied by Tang et al. [1], and Hf was found to be the most effective oxide at refining the formed oxide particles, especially at a concentration of 0.8 wt.\%. Formation of $\mathrm{Y}_{2} \mathrm{Hf}_{2} \mathrm{O}_{7}$ was found to be responsible for oxide particle refinement and consequent improvement in mechanical properties through operation of the Orowan mechanism [9].

Another strengthening mechanism to consider for developing nickel based ODS alloys would be composite strengthening mechanism or load transfer mechanism [10]. For example, studies have also shown that submicron $\mathrm{Al}_{2} \mathrm{O}_{3}$ of $0.5-1 \mu \mathrm{m}$ diameter could be efficient for composite strengthening due to lower density and higher modulus of elasticity $[11,12]$. Hornbogen and Starke [13], and Rosler and Baker [14] predicted that a combination of nanoparticles and coarser particles dispersed in the microstructure would offer both dispersion strengthening and composite strengthening. Through dispersion strengthening and composite strengthening as dominant mechanisms at high temperatures, enhanced mechanical properties would be achieved. 
Nickel based ODS alloys are conventionally produced by mechanical alloying (MA) or ball milling of elemental or pre-alloyed powders in combination with nano-sized $\mathrm{Y}_{2} \mathrm{O}_{3}$ (yttria) powder followed by canning, degassing and consolidation either via hot extrusion (for rods and wires) or hot isostatic pressing (HIP) and rolling (for sheets) [3].

One of the critical steps in producing nickel based ODS alloys is the milling process in which powder blends of yttria and pure nickel or pre-alloyed nickel (for example, Ni-20Cr) are milled, and a fine uniform distribution of yttria particles in the metal matrix can be attained. If powder blends of yttria and two or more metal powders are milled in addition to homogeneous yttria dispersion, formation of solid solution may be also achieved [3]. During milling, the metal powder particles become trapped between the colliding balls (milling media) and are cold welded together while the oxide particles become progressively finer until trapped between layers of metal powders sandwich forming a composite. After cold welding and particle agglomeration, a fracture stage occurs and large composite powders break down until a steady state situation is reached between cold welding and fracturing. Consequently, a uniform distribution of oxide nanoparticles within metallic components would be achieved $[15,16]$.

In conventional consolidation methods such as extrusion or HIP, a final annealing at high temperature is usually required to develop a stable coarse grain structure [16]. The numbers of thermal processing steps could be eliminated if a pulsed direct current (DC) is simultaneously used with a uniaxial pressure to primarily sinter the powders $[17,18]$. This could reduce the time, cost and possibly deformation texture in the consolidated materials [19]. Field activated sintering technique (FAST), also known as spark plasma sintering (SPS) or pulsed electric current sintering (PECS), applies a pulsed DC to enhance sintering rate of the powders to near full density at relatively lower temperatures. Pulsed DC flows through the die and powder compact producing heat via Joule heating mechanism, providing a much higher heating rate and shorter sintering time compared to conventional sintering techniques. Thus, grain growth during sintering can be essentially minimized, leading to improvement in mechanical properties [18, 20-22].

There are limited reported applications of SPS in the processing of nickel based ODS alloys containing $\mathrm{Y}_{2} \mathrm{O}_{3}$ as dispersoids $[1,2,4,23,24]$. Park et al. [2] developed $\mathrm{Ni}-22 \mathrm{Cr}-11 \mathrm{Fe}-1 \mathrm{TiO} \mathrm{O}_{2}$, Ni$22 \mathrm{Cr}-11 \mathrm{Fe}-1 \mathrm{Y}_{2} \mathrm{O}_{3}$ and $\mathrm{Ni}-22 \mathrm{Cr}-11 \mathrm{Fe}-0.5 \mathrm{TiO}_{2}-0.5 \mathrm{Y}_{2} \mathrm{O}_{3}$ (wt. $\%$ ) by milling for $40 \mathrm{~h}$ in a planetary ball mill and SPSed the ball milled powder at $1100{ }^{\circ} \mathrm{C}$ for 5 min under a pressure of $40 \mathrm{MPa}$. They suggested that nano-sized $\mathrm{TiO}_{2}$ and $\mathrm{Y}_{2} \mathrm{O}_{3}$ particles dissolved during $\mathrm{MA}$, and then precipitated out during SPS, forming Y-Ti-O particles. However, Ni-22Cr- $11 \mathrm{Fe}-1 \mathrm{Y}_{2} \mathrm{O}_{3}$ exhibited the best mechanical properties among all of the developed alloys.

In the present study, Ni-20Cr-1.2 $\mathrm{Y}_{2} \mathrm{O}_{3}$ (wt.\%) alloy was processed by ball milling and SPS, and the effects of milling time and sintering parameters on the properties of sintered nickel based 
ODS alloy were investigated. There have been very limited studies on the effects of milling on the microstructural evolution during milling of nickel based powder [25]. Lopez et al. [25] milled elemental $\mathrm{Ni}$ and $\mathrm{Cr}$ powders for $30 \mathrm{~h}$ to obtain a nanostructured $\mathrm{Ni}-20 \mathrm{Cr}$ alloy. Such solid solutionizing reaction occurred mainly due to chemical-heterogeneity-driven diffusion through interfaces, subgrain boundaries and dislocation cores. In this study, Ni-20Cr, and Ni-20Cr- $1.2 \mathrm{Y}_{2} \mathrm{O}_{3}$ $5 \mathrm{Al}_{2} \mathrm{O}_{3}$ (wt.\%) alloys were processed by milling and SPS, and their mechanical properties and microstructural evolution were studied in detail. Here, $1.2 \mathrm{Y}_{2} \mathrm{O}_{3}$ wt.\% (or 2 vol.\%) and $5 \mathrm{Al}_{2} \mathrm{O}_{3}$ wt.\% (or $10 \mathrm{vol} . \%$ ) were added to $\mathrm{Ni}-20 \mathrm{Cr}$ matrix for dispersion strengthening and composite strengthening, respectively.

\section{Experimental}

\subsection{Powder processing and characterization}

Gas atomized Ni-20Cr powder with nominal composition of Ni-19.6Cr-0.2Fe-0.8Mn-0.9Si (wt.\%) and mean particle size of 23.6 $\pm 1.1 \mu \mathrm{m}$; yttrium oxide (yttria/ $\mathrm{Y}_{2} \mathrm{O}_{3}$ ) powder with high purity $\left(99.99 \%\right.$ ) and mean particle size of $30-40 \mathrm{~nm}$; and aluminum oxide (alumina/ $\mathrm{Al}_{2} \mathrm{O}_{3}$ ) powder with 99.99\% purity and mean particle size of 300-400 nm were all procured from the American Elements Inc.

Powder batches were prepared in a glove box under high purity argon atmosphere and poured into hardened steel grinding vial (Spex 8001). In order to minimize powder agglomeration and cold welding during milling, 1 wt.\% stearic acid was added to the powder mix prior to the ball milling process as a process control agent (PCA). The ball milling was carried out in a Spex 8000M shaker mixer/mill using steel balls $5 \mathrm{~mm}$ in diameter and a ball to powder ratio (BPR) of 10:1 (the powder mass and the ball mass of each batch was $10 \mathrm{~g}$ and $100 \mathrm{~g}$, respectively). A variety of Nibased alloys altering in milling time ( $0 \mathrm{~h}, 2 \mathrm{~h}$ and $4 \mathrm{~h}$ ) and nominal composition (Ni-20Cr, Ni-20Cr$1.2 \mathrm{Y}_{2} \mathrm{O}_{3}, \mathrm{Ni}-20 \mathrm{Cr}-1.2 \mathrm{Y}_{2} \mathrm{O}_{3}-5 \mathrm{Al}_{2} \mathrm{O}_{3}$, wt.\%) were milled.

For preparing the Ni-20Cr-1.2 $\mathrm{Y}_{2} \mathrm{O}_{3}-5 \mathrm{Al}_{2} \mathrm{O}_{3}$ powder, Ni-20Cr-1.2 $\mathrm{Y}_{2} \mathrm{O}_{3}$ was first milled for 2 $\mathrm{h}$, and then $5 \mathrm{wt} . \% \mathrm{Al}_{2} \mathrm{O}_{3}$ powder was added to the milled $\mathrm{Ni}-20 \mathrm{Cr}-1.2 \mathrm{Y}_{2} \mathrm{O}_{3}$ alloy and subsequently ball milled to distribute all the $\mathrm{Al}_{2} \mathrm{O}_{3}$ particles homogeneously. In our former experiments, $\mathrm{Al}_{2} \mathrm{O}_{3}$ powder was only blended (i.e. milled without the steel balls) with the milled $\mathrm{Ni}-20 \mathrm{Cr}-1.2 \mathrm{Y}_{2} \mathrm{O}_{3}$ powder, and the results were unsatisfactory because all the $\mathrm{Al}_{2} \mathrm{O}_{3}$ powder particles were found to be mostly located on the prior particle boundaries after consolidation.

$\mathrm{X}$-ray diffraction (XRD) experiments of the as-milled powders were performed using a Siemens 5000D diffractometer with $\mathrm{Cu}-\mathrm{K} \alpha$ radiation. Modifications such as $\mathrm{k} \alpha_{2}$ Rachinger and background correction by Sonnerveld were applied to XRD patterns using the Powder-X software [26]. Lattice parameters, crystallite size and lattice strain were calculated based on the Nelson-Riley 
extrapolation [27] and Williamson-Hall (W-H) formula, respectively [28]. For the instrumental broadening correction, a fully annealed/unmilled Ni-20Cr powder sample was used as a standard.

The morphology and size distribution of the as-received powder batches and as-milled powder were analyzed using a Zeiss Supra 35 field-emission gun scanning electron microscope (FEG-SEM). The milled powders were hot mounted in phenolic powder and polished to $0.05 \mu \mathrm{m}$. The cross section of the hot mounted and polished milled powders were observed in backscatter electron (BSE) mode in SEM. A SEM micrograph obtained from the as received $\mathrm{Al}_{2} \mathrm{O}_{3}$ powder is shown in Fig. 1 and a high angle annular dark field (HAADF) scanning transmission electron microscopy (STEM) micrograph is presented in Fig. 1b.

\subsection{Spark plasma sintering}

The ball milled powder was consolidated via SPS using a Dr. Sinter Lab SPS-515S machine (SPS Syntex Inc., Kanagawa, Japan) with maximum capacity of $30 \mathrm{kN}$ and 1500 A. A Tri-Gemini cylindrical graphite die with an inner diameter of $12.7 \mathrm{~mm}$ and an outer diameter of $38 \mathrm{~mm}$ were used. The inner surface of the die and radial surfaces of punches were covered with a graphite foil $(0.25 \mathrm{~mm}$ in thickness) to facilitate the removal of the sintered specimens. In order to inhibit the diffusion of carbon from the punches and graphite foil to the powder mixture, a thin niobium foil (0.06 $\mathrm{mm}$ in thickness) was placed between the powder and the graphite foils. The die was wrapped in graphite felt ( $4 \mathrm{~mm}$ in thickness) to minimize heat loss by thermal radiation.

All the SPS experiments were performed under vacuum $\left(7 \times 10^{-3}\right.$ Torr or $\left.0.9 \mathrm{~Pa}\right)$, using a heating rate of $100{ }^{\circ} \mathrm{C} / \mathrm{min}$ and force of $10 \mathrm{kN}$ (equals to about $80 \mathrm{MPa}$ considering punch configuration used in this study). An intermediate 15 min dwell time at $450{ }^{\circ} \mathrm{C}$ (with $4.5 \mathrm{kN}$ applied force) was given for all the SPS runs to allow the stearic acid to volatilize. Following that, the temperature was ramped up to different levels $\left(600{ }^{\circ} \mathrm{C}, 900{ }^{\circ} \mathrm{C}, 1000{ }^{\circ} \mathrm{C}\right.$ and $\left.1100{ }^{\circ} \mathrm{C}\right)$, kept at those temperatures for different times ( 5 and $30 \mathrm{~min}$ ), and cooled down with at the rate of about 50 ${ }^{\circ} \mathrm{C} / \mathrm{min}$. The temperature was monitored by a K-type thermocouple that was inserted into a hole in the die such that the tip was located $6 \mathrm{~mm}$ away from the sintering powder. The final product was in the form of a disk with dimensions of $12.5 \mathrm{~mm}$ in diameter and $8 \mathrm{~mm}$ in thickness. All the Ni-based alloys processed in this study varying in milling times, compositions, sintering temperatures and times are listed in Table 1.

\subsection{Density and microstructural characterization}

Upon SPS, physical density of the bulk specimens was measured using Archimedes' principle with at least six measurements for each specimen. The final relative density was calculated as the ratio between the measured density and the theoretical density of each 
composition. Electron backscattered diffraction (EBSD) study was performed using a JEOL JSM6610LV scanning electron microscope (SEM) equipped with an EDAX/TSL Hikari EBSD system.

The transmission electron microscopy (TEM) specimens were mechanically thinned and electropolished at a temperature of about $-35^{\circ} \mathrm{C}$ using a solution of nitric acid and methanol (10:90, vol.\%) and a Fischione twin-jet polisher operating at $30 \mathrm{~V}$. Microstructural studies were conducted using a JEOL-2010 TEM operating at $200 \mathrm{kV}$. A focused ion beam (FIB) was used to prepare a TEM foil from the specimen with a composition of $\mathrm{Ni}-20 \mathrm{Cr}-1.2 \mathrm{Y}_{2} \mathrm{O}_{3}-5 \mathrm{Al}_{2} \mathrm{O}_{3}$ due to the unsatisfactory results after electropolishing (likely caused by low conductivity of this alloy). FIB experiment was done by using an FEI Quanta 3D FEG instrument with a Ga-ion source.

\subsection{Mechanical characterization}

The sample surface for microhardness testing was mechanically polished using standard metallographic procedures involving grinding and polishing down to $0.5 \mu \mathrm{m}$ finish. The Vickers microhardness tests were performed with a Leco LM100 microhardness tester at $0.5 \mathrm{~kg}_{\mathrm{f}}(5 \mathrm{~N}) \operatorname{load}$ applied for $15 \mathrm{~s}$ on the sintered samples. The microhardness tests were repeated on random spots in the center of each specimen up to 10 times.

Compression testing was performed on an Instron 5982 machine at both $25{ }^{\circ} \mathrm{C}$ and $800{ }^{\circ} \mathrm{C}$ applying a strain rate of $10^{-3} \mathrm{~s}^{-1}$. The disk shaped SPSed specimens were electro-discharge machined to a square-based rectangular prism shape with dimensions of $4 \times 4 \times 6 \mathrm{~mm}$. After compression testing, the deformed sample was cooled in water to maintain the microstructure for further studies planned for our future work.

\section{Results}

\subsection{Effect of milling time}

The powder morphology of the Ni-20Cr- $1.2 \mathrm{Y}_{2} \mathrm{O}_{3}$ powder milled for $0 \mathrm{~h}$ (alloy A), $2 \mathrm{~h}$ (alloy B) and $4 \mathrm{~h}$ (alloy C) are shown in the secondary electron (SE) SEM micrographs in Figs. 2a, 2c and 2e, respectively. The BSE micrographs from the cross sectional view of powders milled for $0 \mathrm{~h}, 2 \mathrm{~h}$ and $4 \mathrm{~h}$, mounted and polished are presented in Figs. 2b, 2d and 2f, respectively.

The morphology of $\mathrm{Ni}-20 \mathrm{Cr}-1.2 \mathrm{Y}_{2} \mathrm{O}_{3}$ powder was a mixture of spherical and irregular particles with a mean diameter of $23.6 \pm 2.1 \mu \mathrm{m}$ uniformly covered with stearic acid and $\mathrm{Y}_{2} \mathrm{O}_{3}$ nanopowder as shown in Fig. 2a. The areas with darker contrast in Fig. $2 \mathrm{~b}$ were due to stearic acid. The morphology of Ni-20Cr-1.2 $\mathrm{Y}_{2} \mathrm{O}_{3}$ powder after $2 \mathrm{~h}$ milling is shown in Fig. 2c and exhibited major agglomeration due to ductile nature of powder particles and high tendency of cold welding at an early stage of milling.

At an early stage of milling $(2 \mathrm{~h})$, the ductile $\mathrm{Ni}-20 \mathrm{Cr}$ powder particles became flat and cold welded, and trapping of $\mathrm{Y}_{2} \mathrm{O}_{3}$ powder particles between Ni-20Cr lamellae likely occurred. The 
morphology of powder particles was round and the mean particle size after $2 \mathrm{~h}$ milling was estimated to be $33.6 \pm 1.5 \mu \mathrm{m}$. The plastic flow and deformed layers in a powder lamella after $2 \mathrm{~h}$ of milling can be clearly discerned in Fig. 2 d. Powder agglomeration continued to occur up to $4 \mathrm{~h}$ as shown in Fig. 2e; however, numerous cracks on the powder particles were detected, too. Accumulation of work hardening led to fatigue and fragmentation within the powder flakes that could refine powder particle upon further milling. The powder shape was round with a mean particle size of $39.4 \pm 3.1 \mu \mathrm{m}$. Figure $2 \mathrm{f}$ revealed significant work hardening, cracks and signs of fragmentation after $4 \mathrm{~h}$ of milling.

The XRD patterns for Ni-20Cr- $1.2 \mathrm{Y}_{2} \mathrm{O}_{3}$ powder after $0 \mathrm{~h}, 2 \mathrm{~h}$ and $4 \mathrm{~h}$ milling (alloys $\mathrm{A}, \mathrm{B}$ and C, respectively) are plotted in Fig. 3. In the XRD pattern of alloy A, the peaks of (111), (200) and (222) confirmed an $f c c$ crystal structure in $\mathrm{Ni}-20 \mathrm{Cr}$ and the remaining peaks presented a cubic crystal structure in $\mathrm{Y}_{2} \mathrm{O}_{3}$. The peaks in the XRD of $\mathrm{Y}_{2} \mathrm{O}_{3}$ were indexed as (222), (400), (411), (422) and (622) in the order of appearance. The Ni-20Cr peaks exhibited significant broadening after $2 \mathrm{~h}$ of milling due to refinement in crystallite size. After $4 \mathrm{~h}$ of milling in alloy $\mathrm{C}$, the distinct $\mathrm{Y}_{2} \mathrm{O}_{3}$ peaks were no longer observed, and the Ni-20Cr peaks shifted to lower diffraction angles as a result of partial dissolution of $\mathrm{Y}_{2} \mathrm{O}_{3}$ in the $\mathrm{Ni}-20 \mathrm{Cr}$ matrix and increasing lattice parameter.

The structural quantification results are summarized in Table 2. The lattice parameters of the $f c c \mathrm{Ni}-20 \mathrm{Cr}$ matrix increased after $4 \mathrm{~h}$ of milling indicating dissolution of $\mathrm{Y}_{2} \mathrm{O}_{3}$. As the milling time increased, the average crystallite size constantly decreased from $44 \mathrm{~nm}$ in the blended powder to 14 $\mathrm{nm}$ after $2 \mathrm{~h}$ of milling, and thereafter decreased to $4 \mathrm{~nm}$ with further milling up to $4 \mathrm{~h}$.

The microstructure of the as-milled Ni-20Cr-1.2 $\mathrm{Y}_{2} \mathrm{O}_{3}$ powder after $2 \mathrm{~h}$ milling is shown in Fig. 4 and exhibited a homogeneous distribution of $\mathrm{Y}_{2} \mathrm{O}_{3}$ particles with reduced diameter of $3 \mathrm{~nm}$ in $\mathrm{Ni}-20 \mathrm{Cr}$ nanocrystalline matrix with reduced average size of $25 \mathrm{~nm}$. The selected area diffraction (SAD) pattern shown in Fig. 4 revealed the presence of a cubic crystal structure of $\mathrm{Y}_{2} \mathrm{O}_{3}$ particles distributed in $\mathrm{Ni}-20 \mathrm{Cr}$ matrix with $f c c$ crystal structure.

The density and microhardness of the Ni-20Cr-1.2 $\mathrm{Y}_{2} \mathrm{O}_{3}$ milled for $0 \mathrm{~h}, 2 \mathrm{~h}$ and $4 \mathrm{~h}$ and then sintered at $1100{ }^{\circ} \mathrm{C}$ for 30 min were measured and summarized in Table 3. Full density (100\%) was achieved after sintering of Ni-20Cr-1.2 $\mathrm{Y}_{2} \mathrm{O}_{3}$ powder milled for $0 \mathrm{~h}$ and $4 \mathrm{~h}$; however the relative density of $2 \mathrm{~h}$ milled and sintered $\mathrm{Ni}-20 \mathrm{Cr}-1.2 \mathrm{Y}_{2} \mathrm{O}_{3}$ powder (alloy $\mathrm{B}$ ) showed a slight reduction in density $(99.55 \%)$. The microhardness values of sintered $\mathrm{Ni}-20 \mathrm{Cr}-1.2 \mathrm{Y}_{2} \mathrm{O}_{3}$ alloys increased with increasing milling time up to $4 \mathrm{~h}$. This hardness increase due to longer milling time are likely due to the refined crystallite size, accumulation of work hardening and formation of complex $\mathrm{Y}-\mathrm{Cr}-\mathrm{O}$ particles specifically after $4 \mathrm{~h}$ of milling as will be shown later.

The microstructure of sintered $\mathrm{Ni}-20 \mathrm{Cr}-1.2 \mathrm{Y}_{2} \mathrm{O}_{3}$ alloys milled for $0 \mathrm{~h}, 2 \mathrm{~h}$ and $4 \mathrm{~h}$ (alloy A, $\mathrm{B}$ and $\mathrm{C}$, respectively) are shown in Figs. 5a-d, respectively. The EBSD micrograph is shown in 
Fig. 5a because the grain size was too large for any TEM micrograph to be presented. That is why EBSD micrograph was replaced with TEM micrograph in Fig. 5a. The grains in Fig. 5a were equiaxed and fully recrystallized with average size of $8 \mu \mathrm{m}$. A high volume fraction of annealing twins and $\Sigma 3$ boundaries were also observed in Fig. 5a. Figure 5b shows a bright field TEM image from the $2 \mathrm{~h}$ milled $\mathrm{Ni}-20 \mathrm{Cr}-1.2 \mathrm{Y}_{2} \mathrm{O}_{3}$ (alloy B) with randomly oriented nanograins smaller than 300 $\mathrm{nm}$. The presence of homogeneously distributed nanoparticles in a large volume fraction led to a significant grain refinement in microstructure of $\mathrm{Ni}-20 \mathrm{Cr}-1.2 \mathrm{Y}_{2} \mathrm{O}_{3}$ alloy. The microstructure of $\mathrm{Ni}$ $20 \mathrm{Cr}-1.2 \mathrm{Y}_{2} \mathrm{O}_{3}$ alloy after milling for $4 \mathrm{~h}$ (alloy $\mathrm{C}$ ) revealed a bimodal grain size distribution containing nanograins with an average size of $120 \mathrm{~nm}$ as shown in Fig. 5c and coarser grains with an average size of $400 \mathrm{~nm}$ as shown in Fig. 5d. The corresponding SAD patterns obtained from Fig. $5 \mathrm{c}$ and Fig. 5d also confirmed this bimodal grain size distribution.

High fraction of straight and annealing twin boundaries were found in all of the sintered Ni20Cr-1.2 $\mathrm{Y}_{2} \mathrm{O}_{3}$ alloys regardless of milling time (alloys A, B and C) as shown in Fig. 5a and Figs. 6a-b, respectively. According to studies, formation of these twin boundaries would significantly reduce the grain boundary energy $\mathrm{Ni}-20 \mathrm{Cr}-1.2 \mathrm{Y}_{2} \mathrm{O}_{3}$ powder during sintering stage [29-31].

These twin boundaries were observed in Ni-20Cr- $1.2 \mathrm{Y}_{2} \mathrm{O}_{3}$ alloy milled for different times $(0$ $\mathrm{h}, 2 \mathrm{~h}$ and $4 \mathrm{~h}$ ) implying that formation of these twin boundaries was due to sintering and is not dependent on milling stage. However, the twin width in the sintered $\mathrm{Ni}-20 \mathrm{Cr}-1.2 \mathrm{Y}_{2} \mathrm{O}_{3}$ alloys was strongly dependent on milling time because narrower twins were observed for alloy milled for longer hours ( $4 \mathrm{~h}$ or alloy $\mathrm{C}$ ) as shown in Fig. 6c. The average twin boundary spacing reduced with increasing milling time and was measured to be $2.6 \mu \mathrm{m}$ in alloy A, $127 \mathrm{~nm}$ in alloy B and $32 \mathrm{~nm}$ in alloy C.

Figures 7a-b show the second phase particles in the sintered $\mathrm{Ni}-20 \mathrm{Cr}-1.2 \mathrm{Y}_{2} \mathrm{O}_{3}$ alloys after milling for 2 and $4 \mathrm{~h}$, respectively. For alloy $\mathrm{B}$, the smallest and the average particle diameter were determined to be $3 \mathrm{~nm}$ and $14 \mathrm{~nm}$, respectively as shown in Fig. 7a. In alloy B, three main categories of oxide particles were found based on energy dispersive spectroscopy (EDS): (1) Nibased oxides in the range of 80-100 nm; (2) Cr-based oxides in the range of 20-60 nm; and (3) Ybased oxides smaller than $<15 \mathrm{~nm}$.

Similarly, the smallest and the average particle diameter were determined to be $2 \mathrm{~nm}$ and 7 $\mathrm{nm}$, respectively for alloy $\mathrm{C}$, as shown in Fig. 7b. The average particle size decreased at a longer milling time. The particles in Fig. 7a were mainly Cr-based oxides or $\mathrm{Y}_{2} \mathrm{O}_{3}$ whereas the majority of particles shown in Fig. $7 \mathrm{~b}$ had chemical composition close to $\mathrm{YCrO}_{3}$. This could be attributed to possible dissolution and decomposition of $\mathrm{Y}_{2} \mathrm{O}_{3}$ and formation of $\mathrm{YCrO}_{3}$ like new compound.

\subsection{Effect of SPS parameters}


The Ni-20Cr-1.2 $\mathrm{Y}_{2} \mathrm{O}_{3}$ alloy, milled for $2 \mathrm{~h}$ was sintered at $600{ }^{\circ} \mathrm{C}$ for $5 \mathrm{~min}$ (alloy D), at $900{ }^{\circ} \mathrm{C}$ for $5 \mathrm{~min}$ (alloy E), at $1000{ }^{\circ} \mathrm{C}$ for $5 \mathrm{~min}$ (alloy $\mathrm{F}$ ), at $1100{ }^{\circ} \mathrm{C}$ for $5 \mathrm{~min}$ (alloy G) and at $1100{ }^{\circ} \mathrm{C}$ for $30 \mathrm{~min}$ (alloy B). The physical density, relative density and microhardness values of these alloys were measured and summarized in Table 4. The density values significantly increased from $72.2 \%$ after sintering at $600{ }^{\circ} \mathrm{C}$ to $99.3 \%$ after sintering at $1000{ }^{\circ} \mathrm{C}$ and only slightly increased to $99.5 \%$ and $99.6 \%$ after sintering at $1100{ }^{\circ} \mathrm{C}$ for 5 and $30 \mathrm{~min}$, respectively. The main densification occurred at $1000{ }^{\circ} \mathrm{C}$ and density values did not significantly improve with further increase of sintering temperature or time.

The microhardness values constantly increased from $130.8 \pm 31.5 \mathrm{HV}$ after sintering at $600{ }^{\circ} \mathrm{C}$ to $556 \pm 5 \mathrm{HV}$ after sintering at $1000{ }^{\circ} \mathrm{C}$ at a constant dwell time $(5 \mathrm{~min})$. However, the microhardness decreased to $470 \pm 8 \mathrm{HV}$ after sintering at $1100{ }^{\circ} \mathrm{C}$ for $5 \mathrm{~min}$ and did not change significantly after a dwell time of $30 \mathrm{~min}$.

The overview of microstructure of $\mathrm{Ni}-20 \mathrm{Cr}-1.2 \mathrm{Y}_{2} \mathrm{O}_{3}$ alloy sintered at $900{ }^{\circ} \mathrm{C}$ (alloy $\mathrm{E}$ ), $1100^{\circ} \mathrm{C}$ for $5 \mathrm{~min}$ (alloy G) and $1100^{\circ} \mathrm{C}$ for $30 \mathrm{~min}$ (alloy B) are shown in Figs. 8a-c, respectively. Subgrains with an average size of $200 \mathrm{~nm}$ were distinguished from each other with arrays of dislocations as shown in Fig. 8a. The grains shown in Fig. 8b were larger with an average size of $350 \mathrm{~nm}$ and separated from each other with well-defined sharp boundaries. After sintering of alloy $\mathrm{B}$ at $1100{ }^{\circ} \mathrm{C}$ for $30 \mathrm{~min}$., the average grain size was reduced even further and an extensive dislocation activity was observed, as shown in Fig. 8c. This could be explained considering that dynamic recrystallization phenomenon likely occurred in the alloy after $30 \mathrm{~min}$ at $1100{ }^{\circ} \mathrm{C}$. During dynamic recrystallization, dislocation activity became significant and led to more grain refinement. Meanwhile, the interaction of nanoparticles with dislocations and mobile boundaries effectively inhibited the grain growth process.

The twinning activity as a function of sintering temperature and time can be observed in Figs. 9a-c. The microstructure of Ni-20Cr-1.2 $\mathrm{Y}_{2} \mathrm{O}_{3}$ alloy sintered at $900{ }^{\circ} \mathrm{C}$ for 5 min (alloy E) shown in Fig. 9a, contained very limited and localized twins with average width of $10 \mathrm{~nm}$ and volume fraction of $2.8 \%$. The average twin boundary spacing and volume fraction significantly increased to $150 \mathrm{~nm}$ and $10 \%$, respectively, after sintering at $1100{ }^{\circ} \mathrm{C}$ for 5 min (alloy G) as shown in Fig. 9b. Twins in Ni-20Cr-1.2 $\mathrm{Y}_{2} \mathrm{O}_{3}$ alloy sintered at $1100{ }^{\circ} \mathrm{C}$ for $30 \mathrm{~min}$ (alloy B) are shown in Figure 9c, and the average twin boundary spacing and volume fraction were estimated to be $127 \mathrm{~nm}$ and $11.6 \%$, respectively. With increasing sintering time from 5 to $30 \mathrm{~min}$, the twin boundary width was reduced slightly, but twin boundary volume fraction increased slightly. This could be attributed to the smaller grain size with a higher density of grain boundary areas in alloy B. 
The oxide particles in alloy $\mathrm{E}$ and $\mathrm{G}$ are shown in Figs. 10a-b, respectively. The oxide particles in alloy B were formerly shown in Fig. 7a and thus not repeated here. The average particle size in alloy E was measured to be $4.1 \mathrm{~nm}$, and the smallest particle size was found to be $2 \mathrm{~nm}$. Similarly, for alloy G, the average particle size was $12 \mathrm{~nm}$, and the smallest particle size was $4 \mathrm{~nm}$. The oxide particle size increased with increasing sintering temperature and time, plausibly due to faster kinetics of diffusion and particle coarsening at higher sintering temperature and longer sintering time.

\subsection{Effect of alloy composition}

The physical density, relative density and microhardness values of different alloy compositions; $\mathrm{Ni}-20 \mathrm{Cr}$ (alloy $\mathrm{H}$ ), Ni-20Cr-1.2 $\mathrm{Y}_{2} \mathrm{O}_{3}$ (alloy B) and $\mathrm{Ni}-20 \mathrm{Cr}-1.2 \mathrm{Y}_{2} \mathrm{O}_{3}-5 \mathrm{Al}_{2} \mathrm{O}_{3}$ (alloy I), were evaluated and are summarized in Table 5. Adding 1.2 wt. $\% \mathrm{Y}_{2} \mathrm{O}_{3}$ to Ni-20Cr alloy increased the relative density from $98.95 \pm 0.03 \%$ to $99.55 \pm 0.04 \%$; however, addition of 5 wt.\% $\mathrm{Al}_{2} \mathrm{O}_{3}$ to $\mathrm{Ni}-20 \mathrm{Cr}-1.2 \mathrm{Y}_{2} \mathrm{O}_{3}$ slightly decreased the relative density to $99.18 \pm 0.02 \%$. The microhardness values showed significant increase from $307 \pm 3 \mathrm{HV}$ in $\mathrm{Ni}-20 \mathrm{Cr}$ alloy to $472 \pm 8 \mathrm{HV}$ in $\mathrm{Ni}-20 \mathrm{Cr}-1.2 \mathrm{Y}_{2} \mathrm{O}_{3}$ and $505 \pm 10 \mathrm{HV}$ in $\mathrm{Ni}-20 \mathrm{Cr}-1.2 \mathrm{Y}_{2} \mathrm{O}_{3}-5 \mathrm{Al}_{2} \mathrm{O}_{3}$ alloy.

The microstructures of $\mathrm{Ni}-20 \mathrm{Cr}$ (alloy $\mathrm{H}$ ), Ni-20Cr-1.2 $\mathrm{Y}_{2} \mathrm{O}_{3}$ (alloy $\mathrm{B}$ ) and $\mathrm{Ni}-20 \mathrm{Cr}$ $1.2 \mathrm{Y}_{2} \mathrm{O}_{3}-5 \mathrm{Al}_{2} \mathrm{O}_{3}$ (alloy $\mathrm{I}$ ) are displayed in Figs. 11a-c, respectively. The microstructure of the Ni$20 \mathrm{Cr}$ alloy contained fully recrystallized grains with well-defined sharp boundaries and fewer dislocations as shown in Fig. 11a. The average grain size of the Ni-20Cr alloy was measured to be $630 \mathrm{~nm}$, and the number density of oxide particles was less than that of $\mathrm{Ni}-20 \mathrm{Cr}-1.2 \mathrm{Y}_{2} \mathrm{O}_{3}$ earlier shown in Fig. 7a. The effect of $\mathrm{Y}_{2} \mathrm{O}_{3}$ addition on the grain refinement was clearly evident in Fig. 11b. The presence of homogeneously distributed nanodispersoids in a large volume fraction led to a higher microhardness and grain refinement in the Ni-20Cr-1.2 $\mathrm{Y}_{2} \mathrm{O}_{3}$ alloy.

The microstructure of Ni-20Cr-1.2 $\mathrm{Y}_{2} \mathrm{O}_{3}-5 \mathrm{Al}_{2} \mathrm{O}_{3}$ (alloy I) is shown in Fig. 11c and revealed randomly oriented grains with extensive dislocation activity and an average grain size of $385 \mathrm{~nm}$. The microstructure of $\mathrm{Ni}-20 \mathrm{Cr}$ alloy sintered at $1100{ }^{\circ} \mathrm{C}$ for $30 \mathrm{~min}$ (alloy $\mathrm{H}$ ), contained twins with average width of $161 \mathrm{~nm}$ and volume fraction of $9 \%$ as shown in Fig. 12a. The average twin width and volume fraction in $\mathrm{Ni}-20 \mathrm{Cr}-1.2 \mathrm{Y}_{2} \mathrm{O}_{3}$ (alloy B) were determined to be $127 \mathrm{~nm}$ and $11.6 \%$, respectively as previously shown in Fig. 6a. The average twin width and volume fraction were found to be $60 \mathrm{~nm}$ and $16.1 \%$ in the microstructure of Ni-20Cr-1.2 $\mathrm{Y}_{2} \mathrm{O}_{3}-5 \mathrm{Al}_{2} \mathrm{O}_{3}$ (alloy $\mathrm{I}$ ) shown in Fig. 12b. Thus, addition of 5 wt. $\% \mathrm{Al}_{2} \mathrm{O}_{3}$ to $\mathrm{Ni}-20 \mathrm{Cr}-1.2 \mathrm{Y}_{2} \mathrm{O}_{3}$ alloy led to a higher volume fraction of twins with narrower width.

The size distribution of second phase particles in $\mathrm{Ni}-20 \mathrm{Cr}$ (alloy $\mathrm{H}$ ) is shown in Fig. 13a. Coarser particles were found to be mostly located on the grain boundaries. The oxide particles in $\mathrm{Ni}-20 \mathrm{Cr}-1.2 \mathrm{Y}_{2} \mathrm{O}_{3}$ (alloy B) were previously shown in Fig. 7a. A HAADF STEM micrograph 
obtained from Ni-20Cr-1.2 $\mathrm{Y}_{2} \mathrm{O}_{3}-5 \mathrm{Al}_{2} \mathrm{O}_{3}$ (alloy I) is shown in Fig. 13b. The ultrafine particles with darker contrast and smaller than $400 \mathrm{~nm}$ were more enriched in Al. Figure $13 \mathrm{c}$ revealed oxide particles with diameter varying from $2-3 \mathrm{~nm}$ to $50 \mathrm{~nm}$ in alloy $\mathrm{I}$.

The combined results of XRD, SEM/EDS and TEM/EDS revealed the presence of $\mathrm{Cr}_{2} \mathrm{O}_{3}$, $\mathrm{Cr}_{2} \mathrm{O}_{5}, \mathrm{Y}_{2} \mathrm{O}_{3}, \mathrm{Y}_{2} \mathrm{CrO}_{4}$, and $\mathrm{YCrO}_{3}$ as well as $\mathrm{Cr}_{3} \mathrm{C}_{2}$ and $\mathrm{Cr}_{7} \mathrm{C}_{3}$ in SPSed Ni-20Cr and Ni-20Cr$1.2 \mathrm{Y}_{2} \mathrm{O}_{3}$ alloys. Some of these particles were not observed in TEM due to the electropolishing artifact. The types of particles in $\mathrm{Ni}-20 \mathrm{Cr}-1.2 \mathrm{Y}_{2} \mathrm{O}_{3}-5 \mathrm{Al}_{2} \mathrm{O}_{3}$ (alloy I) varied between $\mathrm{Al}_{2} \mathrm{O}_{3}, \mathrm{YAlO}_{3}$ and negligible percentage of $\mathrm{CrAlO}_{3}$. The particle size distributions were calculated from TEM micrographs using following equation [1];

$$
\lambda=\left[\left(\frac{3 \pi}{4 f}\right)^{1 / 2}-1.64\right] r
$$

where $\lambda$ is the mean particle separation $(\mathrm{nm}), r$ is the mean particle radius and $f$ is the volume fraction of dispersion particles based on several TEM micrographs. Approximately 500 particles were considered for these calculations for better statistical data. For Ni-20Cr, the average particle diameter, average particle radius and mean particle separation were determined to be $88 \mathrm{~nm}, 44 \mathrm{~nm}$ and $187 \mathrm{~nm}$, respectively. From the TEM micrographs of $\mathrm{Ni}-20 \mathrm{Cr}-1.2 \mathrm{Y}_{2} \mathrm{O}_{3}$ alloy, the average particle diameter, average particle radius and mean particle separation were determined to be 14 $\mathrm{nm}, 7 \mathrm{~nm}$ and $58 \mathrm{~nm}$, respectively. For Ni-20Cr- $1.2 \mathrm{Y}_{2} \mathrm{O}_{3}-5 \mathrm{Al}_{2} \mathrm{O}_{3}$, the average dispersion oxide particle diameter, average particle radius and mean particle separation were determined to be 22 $\mathrm{nm}, 11 \mathrm{~nm}$ and $72 \mathrm{~nm}$, respectively. In this calculation, the coarser particles enriched in $\mathrm{Al}$ were not included.

The particle size distribution histograms for different alloy compositions are shown in Figs. 14a-c. A broad range of oxide particles were observed in Ni-20Cr alloy as shown Fig. 14a. With addition of $\mathrm{Y}_{2} \mathrm{O}_{3}$ to Ni-20Cr, both average particle diameter and mean particle separation decreased significantly. In Ni-20Cr- $1.2 \mathrm{Y}_{2} \mathrm{O}_{3}-5 \mathrm{Al}_{2} \mathrm{O}_{3}$ alloy, there was a range of nanoparticles smaller than 15 $\mathrm{nm}$ and coarser particles larger than $250 \mathrm{~nm}$.

The compression tests were performed on Ni-20Cr, Ni-20Cr-1.2 $\mathrm{Y}_{2} \mathrm{O}_{3}$ and $\mathrm{Ni}-20 \mathrm{Cr}-1.2 \mathrm{Y}_{2} \mathrm{O}_{3}$ $5 \mathrm{Al}_{2} \mathrm{O}_{3}$ alloys at $25{ }^{\circ} \mathrm{C}$ and $800{ }^{\circ} \mathrm{C}$ by applying a strain rate of $10^{-3} \mathrm{~s}^{-1}$. The results are summarized in Table 6. The true compression stress-plastic strain plots (at $800{ }^{\circ} \mathrm{C}$ ) for different compositions are illustrated in Fig. 15.

\section{Discussion}

\subsection{Microstructural evolution}

During high energy ball milling several phenomena could occur; initially Ni-20Cr powder particles agglomerate and then continue to form fine lamellar sandwich structure until they break up 
due to high energy colliding balls at later stages [25]. After milling of Ni-20Cr-1.2 $\mathrm{Y}_{2} \mathrm{O}_{3}$ alloy for 2 h, Ni-20Cr powder became cold-welded and $\mathrm{Y}_{2} \mathrm{O}_{3}$ particles became finer and increased the interfacial energy (Figs. 2c-d). As milling proceeded for $4 \mathrm{~h}$, accumulative plastic strain became significant and caused crack initiation in the milled particles as shown in Fig. 2f. After $4 \mathrm{~h}$ of milling, $\mathrm{Y}_{2} \mathrm{O}_{3}$ particles had a sufficient driving force for decomposition. The peak broadening effect shown in Fig. 3 can be attributed to the progressive reduction in crystallite size (i.e. grain refinement) and increase in lattice strain arising from crystal imperfections (vacancies and dislocations) and severe plastic deformation induced by high energy ball milling. No peak of $\mathrm{Y}_{2} \mathrm{O}_{3}$ was observed in the XRD pattern corresponding to $4 \mathrm{~h}$ milling and shown in Fig. 3. Dissolution of $\mathrm{Y}_{2} \mathrm{O}_{3}$ in Ni-20Cr matrix was not the goal of the milling experiments; rather the intention of this study was to homogeneously distribute $\mathrm{Y}_{2} \mathrm{O}_{3}$ fine particles in the Ni-20Cr matrix as shown in Figs. 4a-b. So, further milling experiments were continued up to $2 \mathrm{~h}$.

In alloy A, there was no milling and plastic deformation involved prior to sintering, so large particles and crystallites of $\mathrm{Ni}-20 \mathrm{Cr}$ were recrystallized by hot deformation caused during SPS. Non-uniformly distributed $\mathrm{Y}_{2} \mathrm{O}_{3}$ particles were located at prior particle boundaries upon consolidation. The recrystallized grains were dislocation free, equiaxed and without any preferred texture.

In alloy B, recrystallization and grain growth were efficiently controlled by a high volume fraction of oxide nanoparticles with mean particle separation of $58 \mathrm{~nm}$ and average radius of $7 \mathrm{~nm}$ (smallest particle size of $3 \mathrm{~nm}$ ).

With further milling for $4 \mathrm{~h}$, there was a tendency for developing a bimodal grain structure in the sintered alloy as shown in Figs. 5c-d. The reason for the bimodal grain size distribution was likely due to heterogeneous plastic deformation and dissolution of $\mathrm{Y}_{2} \mathrm{O}_{3}$ in $\mathrm{Ni}-20 \mathrm{Cr}$ matrix after milling for $4 \mathrm{~h}$. Because the heterogeneity in Ni-20Cr powder particles incorporated by longer milling hours from one hand and alteration in chemical compositions from one particle to another particle or from inside to outside of a particle in another hand could initiate the bimodal grain structure [25]. More distinct bimodal grain size distribution has already been reported for the ironbased ODS alloys and was attributed to heterogeneity developed in the microstructure due to long hours of milling and subsequent sintering process $[17,32,33]$.

Microstructures of the sintered Ni-20Cr- $1.2 \mathrm{Y}_{2} \mathrm{O}_{3}$ alloy milled for $0 \mathrm{~h}, 2 \mathrm{~h}$ and $4 \mathrm{~h}$ comprised multiple twin boundaries as shown in Fig. 5a and Figs. 6a-c. With increasing milling time from $0 \mathrm{~h}$ to $4 \mathrm{~h}$, twin boundaries width reduced and volume fraction of twinned boundaries increased.

Presence of twin boundaries in $0 \mathrm{~h}$ milled sintered Ni-20Cr- $1.2 \mathrm{Y}_{2} \mathrm{O}_{3}$ (alloy A) implied that twin boundary formation may not depend on milling process, rather, it depended on thermal and sintering process. Annealing twins have been frequently observed during grain growth of nickel at 
temperatures of $0.68 \mathrm{~T}_{\mathrm{m}}$ and above (i.e. $\geq 950{ }^{\circ} \mathrm{C}$ ) [30], and were associated with annealing temperature. Formation of twin boundaries in nickel alloys is because of their low stacking fault energy. For example, adding only 0.04 mole fraction of $\mathrm{Cr}$ as an alloying element to pure $\mathrm{Ni}$ decreases the stacking fault energy of the alloy by $40 \mathrm{~mJ} / \mathrm{m}^{2}$ [34].

The longer milling time would produce the smaller crystallize size and consequently the narrower twin boundaries. It is because smaller crystallite size would significantly limit the space in grain interior for the twins in order to nucleate and grow [35]. Besides, crystallographic orientation would alter more frequently in nanograins and lead to narrower twins.

Twin volume fraction was approximately determined to be $8.5 \%, 11.6 \%$ and $16.8 \%$ for alloys A, B and C, respectively. The twin volume fraction increased at longer milling time. The accurate measurement of twin volume fraction is usually challenging because some twins may not be visible in TEM if the grains are not oriented at certain orientation or angles. Longer milling time produced higher amount of plastic deformation and stored energy. Higher amount of stored energy in the crystallites and crystallite boundaries of Ni-20Cr-1.2 $\mathrm{Y}_{2} \mathrm{O}_{3}$ alloy could effectively lower the activation energy and favor the twin boundary formation. Twin boundaries are mobile during sintering and could minimize the grain boundary energy and total interfacial energy independently of grain growth and grain boundary migration [30]. Therefore, higher amount of stored energy in the milled powder can be lowered during sintering through the formation of higher volume of twin boundaries.

The size and chemical composition of oxide particles found in the sintered $\mathrm{Ni}-20 \mathrm{Cr}-1.2 \mathrm{Y}_{2} \mathrm{O}_{3}$ alloys Fig. 7a-c could be different from each other as a function of milling time. It is likely that during SPS at the elevated temperatures, $\mathrm{Cr}$ started precipitating out of the Ni-Cr solid solution in the form of $\mathrm{Cr}$ based oxides and carbides [23]. The oxide particles of alloy B as shown in Fig. 7b were mostly Cr-based and Y-based oxides. However, the oxide particles of alloy $\mathrm{C}$ shown in Fig. 7c had composition close to $\mathrm{Y}-\mathrm{Cr}-\mathrm{O}$. This could be due to decomposition of $\mathrm{Y}_{2} \mathrm{O}_{3}$ after $4 \mathrm{~h}$ milling as confirmed by XRD results (shown in Fig. 3), and re-precipitation along with Cr to form smaller and more stable particles [8]. Similar behavior was also reported in previous studies where the original $\mathrm{Y}_{2} \mathrm{O}_{3}$ particles led changed into other complex more stable oxides (for example Y-Ti-O, Y-Cr-O and Y-Al-O) [4, 36-38].

The enthalpy of formation of $\mathrm{YCrO}_{3}$ and $\mathrm{Y}_{2} \mathrm{O}_{3}$ are -1493 and $-1907 \mathrm{~kJ} / \mathrm{mol}$, respectively [39]. Despite the high enthalpy of formation for $\mathrm{Y}-\mathrm{O}$, the formation of $\mathrm{Y}$-Cr-oxides could be promoted due to higher concentration and diffusivity of $\mathrm{Cr}$ compared to $\mathrm{Y}$ [33, 40]. This was provided via accumulated lattice imperfections (vacancies and dislocations) introduced by longer milling times. 
The SPS parameters such as temperature, time, heating rate and applied pressure could significantly influence the mechanical properties and microstructural evolution. In the present study, only the effects of SPS temperature and time were investigated on alloys D, E, F, G and B.

Densification constantly improved with increasing SPS temperature; however, microhardness decreased at $1100{ }^{\circ} \mathrm{C}$ due to potential coarsening of oxide particles. The subgrains formed at $900{ }^{\circ} \mathrm{C}$ were distinguished by arrays of dislocations and revealed a recovered microstructure as shown in Fig. 8a. However, after SPS at $1000{ }^{\circ} \mathrm{C}$, most of the grains became larger, recrystallized and separated from one another with sharp boundaries as shown in Fig. 8b. The grain size and microhardness at $1100{ }^{\circ} \mathrm{C}$ did not change with increasing time from 5 min to 30 min, suggesting that for SPS, temperature was more dominant than time.

Dislocations observed in Fig. $8 \mathrm{c}$ could not be due to work hardening since the hardness values did not show any significant change between alloy $\mathrm{G}\left(1100^{\circ} \mathrm{C}\right.$ for $\left.5 \mathrm{~min}\right)$ and $\mathrm{B}\left(1100{ }^{\circ} \mathrm{C}\right.$ for $30 \mathrm{~min}$ ). They could be due to dynamic recrystallization continuously occurring during SPS with increasing time from $5 \mathrm{~min}$ to $30 \mathrm{~min}$.

Lower hardness of alloy E compared to alloy $\mathrm{G}$ and $\mathrm{B}$ could be due to less volume fraction of twin boundaries as shown in Figs. 9a-c. Annealing twins could contribute to hardness by blocking dislocations and mobile grain boundaries [41]. Increasing SPS temperature increased volume fraction of the annealing twinsalong with increase in their width. Increasing sintering time did not significantly change twin boundary properties. Recrystallization process is controlled by oxide dispersion and one way to facilitate the recrystallization stage is through twin formation. In other words, higher sintering temperature may lower the activation energy of twin formation because twinned grains can facilitate recrystallization [42].

Similar twin activities have recently been reported in powder processing and SPS of bulk multimodal nickel [41]. Fang et al. [43] suggested that during the SPS process and applying a high uniaxial pressure (80 MPa), certain parallel crystallographic planes might slip toward an opposite direction maintaining a certain crystallographic distance from each other. This approach could activate a certain twin boundary system by a critical resolved shear stress that could be achieved at higher sintering temperatures. Randle et al. [30] suggested that twin formation kinetics in nickel may actually be independent of grain growth and the relationship between grain growth and twin formation may be only coincidentally related with temperature. Nonetheless, the origin of annealing twins in Ni alloys is still a matter of conjecture.

Oxide particle size significantly increased with increasing SPS temperature as shown in Figs. 10a-b with smallest oxide particle size found in alloy $\mathrm{E}\left(900{ }^{\circ} \mathrm{C}\right.$ for $\left.5 \mathrm{~min}\right)$. In the present study, sintering time did not cause any significant oxide particle coarsening. Sequential adding of 
$\mathrm{Y}_{2} \mathrm{O}_{3}$ and $\mathrm{Al}_{2} \mathrm{O}_{3}$ to $\mathrm{Ni}-20 \mathrm{Cr}$ significantly improved the hardness due to grain refinement and high density of oxide nanoparticles as shown in Figs. 11a-c.

Fully recrystallized microstructure with less density of particles was observed in $\mathrm{Ni}-20 \mathrm{Cr}$ alloy. The microstructure of $\mathrm{Ni}-20 \mathrm{Cr}-1.2 \mathrm{Y}_{2} \mathrm{O}_{3}$ and $\mathrm{Ni}-20 \mathrm{Cr}-1.2 \mathrm{Y}_{2} \mathrm{O}_{3}-5 \mathrm{Al}_{2} \mathrm{O}_{3}$ alloys revealed nanograins with higher density of dislocations and oxide nanoparticles.

Higher volume fraction of second phase particles or oxide particles increased the volume fraction of twin boundaries and reduced width of twin/matrix lamellae (Figs. 12a-b). The presence of high volume fraction of precipitates and solutes at the boundaries of $\mathrm{Ni}-20 \mathrm{Cr}-1.2 \mathrm{Y}_{2} \mathrm{O}_{3}$ and Ni$20 \mathrm{Cr}-1.2 \mathrm{Y}_{2} \mathrm{O}_{3}-5 \mathrm{Al}_{2} \mathrm{O}_{3}$ alloys might impede the grain rotations and increase the activation energy of grain rotations [44]. This could facilitate and ease formation of more annealing twins with narrower width and higher volume fraction.

\subsection{Mechanical properties and strengthening mechanisms}

Higher hardness values with increasing milling time could be attributed to smaller crystallite size, more plastic strain and narrower twin width. Because annealing twins are considered as obstacles to dislocation motion especially when the width of twin/matrix lamellae decreases [41, 43]. Microhardness values were $307 \pm 3 \mathrm{HV}$ for $\mathrm{Ni}-20 \mathrm{Cr}$ alloy, $471.6 \pm 7.5 \mathrm{HV}$ in $\mathrm{Ni}-20 \mathrm{Cr}-1.2 \mathrm{Y}_{2} \mathrm{O}_{3}$ and $505 \pm 10 \mathrm{HV}$ in $\mathrm{Ni}-20 \mathrm{Cr}-1.2 \mathrm{Y}_{2} \mathrm{O}_{3}-5 \mathrm{Al}_{2} \mathrm{O}_{3}$. Park et al. [2] reported hardness values of $526.3 \mathrm{HV}$ for $\mathrm{Ni}-22 \mathrm{Cr}-11 \mathrm{Fe}-1 \mathrm{TiO}_{2}, 645.3 \mathrm{HV}$ for $\mathrm{Ni}-22 \mathrm{Cr}-11 \mathrm{Fe}-1 \mathrm{Y}_{2} \mathrm{O}_{3}$ and $593.3 \mathrm{HV}$ for $\mathrm{Ni}-22 \mathrm{Cr}-11 \mathrm{Fe}-$ $0.5 \mathrm{TiO}_{2}-0.5 \mathrm{Y}_{2} \mathrm{O}_{3}$ (wt.\%) alloys SPSed at $1100{ }^{\circ} \mathrm{C}$. Tang et al.[1] found adding $0.8 \mathrm{wt} . \% \mathrm{Hf}$ to Ni$0.5 \mathrm{Al}-1 \mathrm{Y}_{2} \mathrm{O}_{3}$ increased the hardness from $360 \mathrm{HV}$ to $460 \mathrm{HV}$.

Higher hardness value in $\mathrm{Ni}-20 \mathrm{Cr}-1.2 \mathrm{Y}_{2} \mathrm{O}_{3}$ alloy compared to that of $\mathrm{Ni}-20 \mathrm{Cr}$ alloy could be attributed to grain refinement and higher volume fraction of homogeneously distributed oxide nanoparticles. The strengthening in Ni-20Cr- $1.2 \mathrm{Y}_{2} \mathrm{O}_{3}-5 \mathrm{Al}_{2} \mathrm{O}_{3}$ alloy could be attributed to combination of solid solution, Hall-Petch (due to grain refinement), precipitation (due to $\mathrm{Y}_{2} \mathrm{O}_{3}$ ) and composite strengthening (due to $\mathrm{Al}_{2} \mathrm{O}_{3}$ particles) mechanisms. The total strengthening was estimated by simple linear addition of all the contributing mechanisms, assuming that strengthening mechanisms operate independently of one another [45]. Hence, $\sigma_{Y}$ can be estimated by following equation;

$\sigma_{Y}=\sigma_{\mathrm{o}}+\Delta \sigma_{S S}+\Delta \sigma_{D+} \Delta \sigma_{G B}+\Delta \sigma_{O r o}+\Delta \sigma_{C}$

where $\sigma_{Y}$ is the estimated yield strength, $\sigma_{o}$ is the Peierls-Nabarro stress or lattice-friction stress and negligible, $\Delta \sigma_{S S}$ the solid solution strengthening contribution, $\Delta \sigma_{D}$ the dislocation strengthening contribution, $\Delta \sigma_{G B}$ the grain boundary strengthening contribution, $\Delta \sigma_{O r o}$ is the Orowan or dispersion mechanism contribution and $\Delta \sigma_{C}$ is the composite strengthening contribution factor. The PeierlsNabarro or lattice-friction stress for an isotropic pure $f c c$ crystal structure at room temperature is generally a negligible quantity (here, a value of $\sigma_{o}=6-8 \mathrm{MPa}$ was assumed) [46]. 


\subsubsection{Solid solution strengthening}

The solid solution strengthening due to multiple alloying elements in $\mathrm{Ni}$ alloys has been investigated [47] and the strengthening can be expressed by the following relation

$$
\Delta \sigma_{S S}=\left(\sum_{i} k_{i}^{1 / n} c_{i}\right)^{n}
$$

where $\Delta \sigma_{s s}$ is the solid solution contribution, $k_{i}$ is the strengthening constant for solute $i, c_{i}$ is the concentration of solute $i$, and $n$ is taken as 0.5 here. For Ni-Cr alloy, the value of $k$ is $337 \mathrm{MPa}$ at. fraction $^{-1 / 2}$ [48]. Considering the nominal composition of $\mathrm{Ni}-20 \mathrm{Cr}$ alloy, the strengthening due to solutes is $158 \mathrm{MPa}$ assuming that the $\mathrm{Y}_{2} \mathrm{O}_{3}$ and $\mathrm{Al}_{2} \mathrm{O}_{3}$ particles did not get dissolved in the matrix.

\subsubsection{Dislocation strengthening}

The contribution of dislocation strengthening can be evaluated by using Bailey-Hirsch equation [49],

$$
\Delta \sigma_{D}=\alpha G b \rho^{1 / 2}
$$

where a value of 0.5 was used for the dislocation strengthening coefficient [50], and $G$ (shear modulus) and $b$ (Burgers vector) were taken as $82 \mathrm{GPa}$ and $0.25 \mathrm{~nm}$, respectively [1, 51]. Using several TEM micrographs, the dislocation density was calculated for the three alloys and estimated to be $3.4 \times 10^{13} \mathrm{~m}^{-2}$ for $\mathrm{Ni}-20 \mathrm{Cr}, 9.6 \times 10^{13} \mathrm{~m}^{-2}$ for $\mathrm{Ni}-20 \mathrm{Cr}-1.2 \mathrm{Y}_{2} \mathrm{O}_{3}$, and $1.2 \times 10^{14} \mathrm{~m}^{-2}$ for Ni-20Cr$1.2 \mathrm{Y}_{2} \mathrm{O}_{3}-5 \mathrm{Al}_{2} \mathrm{O}_{3}$. Therefore, the contributions due to dislocation strengthening were $68 \mathrm{MPa}, 96$ $\mathrm{MPa}$ and $111 \mathrm{MPa}$ for $\mathrm{Ni}-20 \mathrm{Cr}, \mathrm{Ni}-20 \mathrm{Cr}-1.2 \mathrm{Y}_{2} \mathrm{O}_{3}$ and $\mathrm{Ni}-20 \mathrm{Cr}-1.2 \mathrm{Y}_{2} \mathrm{O}_{3}-5 \mathrm{Al}_{2} \mathrm{O}_{3}$, respectively.

\subsubsection{Grain boundary (Hall-Petch) strengthening}

The classic Hall-Petch relationship is used for estimating the grain boundary strengthening contribution. The average grain size for different alloys was measured and presented in the results section. By substituting the obtained average grain sizes in the equation as suggested by Bui et al. [52]:

$\Delta \sigma_{G B}=5538 d^{-1 / 2}$,

the grain boundary strengthening contributions were determined to be $257 \mathrm{MPa}$ for Ni-20Cr, 360 $\mathrm{MPa}$ for $\mathrm{Ni}-20 \mathrm{Cr}-1.2 \mathrm{Y}_{2} \mathrm{O}_{3}$ and $319 \mathrm{MPa}$ for $\mathrm{Ni}-20 \mathrm{Cr}-1.2 \mathrm{Y}_{2} \mathrm{O}_{3}-5 \mathrm{Al}_{2} \mathrm{O}_{3}$ alloy.

\subsubsection{Orowan (dispersion) strengthening}

The additional contribution to yield strength by Orowan strengthening mechanism can be determined by the following equation [53]:

$$
\Delta \sigma_{\text {Oro }}=M \frac{0.4 G b}{\pi \sqrt{1-v}} \frac{\ln \left(\frac{2 r}{b}\right)}{\lambda}
$$

where $r$ is the average particle radius, $\lambda$ the mean particle separation, $f$ the volume fraction of particles, $v$ the Poisson ratio, and $M$ the Taylor factor. The values of $\lambda$ and $f$ were calculated to be 
$187 \mathrm{~nm}$ and 0.055 for $\mathrm{Ni}-20 \mathrm{Cr}, 58 \mathrm{~nm}$ and 0.235 for $\mathrm{Ni}-20 \mathrm{Cr}-1.2 \mathrm{Y}_{2} \mathrm{O}_{3}$, and $72 \mathrm{~nm}$ and 0.19 for Ni$20 \mathrm{Cr}-1.2 \mathrm{Y}_{2} \mathrm{O}_{3}-5 \mathrm{Al}_{2} \mathrm{O}_{3}$ alloys, respectively. In this calculation, $M$ was taken as 3 for fcc materials [54]. Based on these calculations, the contribution of Orowan strengthening mechanism at room temperature was calculated to be $295 \mathrm{MPa}$ for $\mathrm{Ni}-20 \mathrm{Cr}, 650 \mathrm{MPa}$ for $\mathrm{Ni}-20 \mathrm{Cr}-1.2 \mathrm{Y}_{2} \mathrm{O}_{3}$ and 587 $\mathrm{MPa}$ for $\mathrm{Ni}-20 \mathrm{Cr}-1.2 \mathrm{Y}_{2} \mathrm{O}_{3}-5 \mathrm{Al}_{2} \mathrm{O}_{3}$ alloys. The pinning effects imply that the strength of oxide particles depends on particle size and mean particle separation. Therefore, reduction in the mean particle separation and homogeneously distributed $\mathrm{Y}_{2} \mathrm{O}_{3}$ nanoparticles could essentially improve the strength properties in $\mathrm{Ni}-20 \mathrm{Cr}-1.2 \mathrm{Y}_{2} \mathrm{O}_{3}$ compared to $\mathrm{Ni}-20 \mathrm{Cr}$ alloy [1].

\subsubsection{Composite strengthening}

Composite strengthening differs from the dispersion strengthening in terms of particle size, which are much larger. In the particle-reinforced composite, the reinforcement phase is significantly stronger than the matrix and during loading a large fraction of load is transferred to the reinforcement phase. Strength of the discontinuously-reinforced composite depends on the particle size and volume fraction. For uniformly distributed reinforcement in the matrix, the rule of mixture can be used to calculate the net properties of the composite given by the following relation [55]:

$\sigma_{c}=V_{p} \sigma_{p}+V_{m} \sigma_{m}$

where $\sigma_{c}$ is the estimated strength of the composite, $V_{p}$ and $V_{m}$ are the volume fraction of the particle and matrix respectively, $\sigma_{p}$ and $\sigma_{m}$ are the yield strength of the particle and the matrix. Here $\mathrm{Al}_{2} \mathrm{O}_{3}$ particles were added as composite reinforcement phase and its contribution was calculated to be $295 \mathrm{MPa}$ assuming the yield strength value of $2945 \mathrm{MPa}$ and the volume fraction of 0.1 for the $\mathrm{Al}_{2} \mathrm{O}_{3}$ particles.

Table 7 summarizes the contribution of different strengthening mechanisms in $\mathrm{Ni}-20 \mathrm{Cr}, \mathrm{Ni}$ $20 \mathrm{Cr}-1.2 \mathrm{Y}_{2} \mathrm{O}_{3}$ and $\mathrm{Ni}-20 \mathrm{Cr}-1.2 \mathrm{Y}_{2} \mathrm{O}_{3}-5 \mathrm{Al}_{2} \mathrm{O}_{3}$ alloys sintered at $1100{ }^{\circ} \mathrm{C}$ for $30 \mathrm{~min}$ and compares the estimated yield strength values with the experimentally determined ones. The estimated yield strength at room temperatures were found to be very close to the experimental values. For estimating the yield strength values at $800{ }^{\circ} \mathrm{C}$ and investigating deformation mechanisms, microstructural studies of as-compressed specimens are required that will be considered in our future work.

The compression yield strength for the Ni-20Cr alloy was reported to be $790 \mathrm{MPa}$ at $25^{\circ} \mathrm{C}$ and $125 \mathrm{MPa}$ at $800{ }^{\circ} \mathrm{C}$. It appears that the only strengthening mechanism for the Ni-20Cr alloy at $800{ }^{\circ} \mathrm{C}$ was solid solution strengthening and other mechanisms were not actively working at higher temperatures. The compression yield values for $\mathrm{Ni}-20 \mathrm{Cr}-1.2 \mathrm{Y}_{2} \mathrm{O}_{3}$ alloy were reported to be 1286 $\mathrm{MPa}$ at $25{ }^{\circ} \mathrm{C}$ and $225 \mathrm{MPa}$ at $800{ }^{\circ} \mathrm{C}$. The yield value for INCONEL 754 (with nominal 
composition of $\mathrm{Ni}-20 \mathrm{Cr}-0.3 \mathrm{Al}-0.5 \mathrm{Ti}-0.6 \mathrm{Y}_{2} \mathrm{O}_{3}$ ) was reported to be $586 \mathrm{MPa}$ at $25^{\circ} \mathrm{C}$ and $214 \mathrm{MPa}$ at $871{ }^{\circ} \mathrm{C}[56]$.

Figure 16 shows the variation of microhardness and true compression yield stress obtained at room temperature $\left(25^{\circ} \mathrm{C}\right)$ as a function of mean particle separation $(\lambda)$ for different alloy compositions. For Ni-20Cr-1.2 $\mathrm{Y}_{2} \mathrm{O}_{3}$ alloy, high hardness and yield stress values were obtained through the smallest mean particle separation, and for Ni-20Cr, the lower hardness and yield stress values were obtained due to large mean particle separation. This implies that efficiency of dispersion strengthening mechanism increased with lower mean particle separation, resulting in the improved hardness and compression yield values. In case of Ni-20Cr- $1.2 \mathrm{Y}_{2} \mathrm{O}_{3}-5 \mathrm{Al}_{2} \mathrm{O}_{3}$ alloy, high hardness and yield stress values were obtained even though the mean particle separation was slightly larger than that of $\mathrm{Ni}-20 \mathrm{Cr}-1.2 \mathrm{Y}_{2} \mathrm{O}_{3}$ alloy. This demonstrates the efficiency of $\mathrm{Al}_{2} \mathrm{O}_{3}$ particles as the composite reinforcement particles improving the overall hardness.

The yield strength of Ni-20Cr-1.2 $\mathrm{Y}_{2} \mathrm{O}_{3}$ alloy was significantly higher than INCONEL 754 at room temperature and $800^{\circ} \mathrm{C}$. This suggests that strengthening mechanism at high temperatures is due to dispersion of stable oxide particles in both alloys. Because the stable $\mathrm{Y}_{2} \mathrm{O}_{3}$ particles in Ni$20 \mathrm{Cr}-1.2 \mathrm{Y}_{2} \mathrm{O}_{3}$ alloy not only inhibited the dislocation motion and increased the resistance of the matrix to deformation, but also controlled the recovery and recrystallization process and inhibited grain growth. However, for other strengthening mechanisms such as grain boundary strengthening mechanism could be actively working along with the Orowan mechanism in the case of Ni-20Cr$1.2 \mathrm{Y}_{2} \mathrm{O}_{3}$ alloy due to presence of fine grains of the alloy consolidated via SPS. This could be regarded as an advantage of using SPS to consolidate Ni-20Cr-1.2 $\mathrm{Y}_{2} \mathrm{O}_{3}$ alloy with finer grains. It is worth mentioning that the contributions of fine grains and dislocation density to strength is significant at room temperature, but those contributions would diminish significantly or disappear altogether at high temperatures due to propensity for grain boundary sliding and reduction in dislocation density.

\section{Conclusions}

In the present study, Ni-20Cr, Ni-20Cr-1.2 $\mathrm{Y}_{2} \mathrm{O}_{3}$ and $\mathrm{Ni}-20 \mathrm{Cr}-1.2 \mathrm{Y}_{2} \mathrm{O}_{3}-5 \mathrm{Al}_{2} \mathrm{O}_{3}$ were developed via milling and SPS. The effects of milling time, sintering time and temperature, and alloying composition on the overall microstructure including annealing twins, particle size distribution, as well as on the hardness and compressive yield strength of nickel based ODS alloys were investigated. The following conclusions were drawn:

1- The grains in unmilled sintered alloys were in micron size range. The grain size was significantly reduced after 2 and $4 \mathrm{~h}$ of milling. The presence or absence of milling had no influence on manifestation of the twins. However, for longer milling times, higher amount of stored energy 
decreased the activation energy of twin formation and led to a higher volume fraction of twins. The twin width also decreased at longer milling times due to finer crystallites. Longer milling time ( $>4$ h) led to dissolution of $\mathrm{Y}_{2} \mathrm{O}_{3}$ in $\mathrm{Ni}-20 \mathrm{Cr}$ and produced complex $\mathrm{Y}-\mathrm{Cr}-\mathrm{O}$ particles.

2- Higher sintering temperature provided higher hardness and density, and higher volume fraction of twins. The oxide particles were stable up to $1100{ }^{\circ} \mathrm{C}$ and could efficiently control the recrystallization process and inhibit any grain growth.

3- Adding $\mathrm{Y}_{2} \mathrm{O}_{3}$ to $\mathrm{Ni}-20 \mathrm{Cr}$ contributed to significant dispersion hardening and additional presence of coarser $\mathrm{Al}_{2} \mathrm{O}_{3}$ provided composite strengthening to the $\mathrm{Ni}-20 \mathrm{Cr}$ matrix alloy. $\mathrm{A}$ high compression yield stress at $800{ }^{\circ} \mathrm{C}$ was obtained for the $\mathrm{Ni}-20 \mathrm{Cr}-1.2 \mathrm{Y}_{2} \mathrm{O}_{3}-5 \mathrm{Al}_{2} \mathrm{O}_{3}$ alloy.

\section{Acknowledgments}

The support of the University Coal Research Program of the US Department of Energy (DOE) via a grant (DE-FE0008648) managed by the National Energy Technology Laboratory (NETL) is gratefully acknowledged. Also, we would like to thank Professor Darryl P. Butt of the Boise State University and the Center for Advanced Energy Studies (CAES) staff for facilitating access to the SPS instrument.

\section{References}

[1] Q. Tang, T. Hoshino, S. Ukai, B. Leng, S. Hayashi, W. Wang, Mater. Trans. 51 (2010) 2019-2024.

[2] J. Park, J. Jang, T.K. Kim, S.J. Kim, J.H. Ahn, J. Nanosci. Nanotechnol. 11 (2011) 6213-6218.

[3] J. Zibral, Metall. Mater. Trans. 27A (1996) 1371-1377.

[4] M.K. Lee, J.J. Park, C. Rhee C., Mater. Chem. Phys. 137 (2012) 129-134.

[5] D.J. Srolovitz, M.J. Luton, R.A. Petkovic, D.M. Narnett, W.D. Nix, Acta Metall. 32 (1984) 10791084.

[6] E. Artz, J. Rosler, Acta Metall. 36 (1988) 1053-1060.

[7] B. Reppich, Acta Mater. 46 (1998) 61-67.

[8] J.J. Park, H.J. Choe, S.M. Hong, M.K. Lee, C.K. Rhee, Powder Technol. 230 (2012) 139-144.

[9] E. Orowan, in: Symposium on internal stresses in metals and alloys, Institute of Metals, London, 1948. p.451.

[10] R.J. Arsenault, in: Marshall IH (ed.), Composite Structures 4, Springer, Netherlands, 1987, 70-81.

[11] H. Wang, P. Shi, H. Yu, B. Xu, Phys. Procedia 50 (2013) 225-230.

[12] A.K. Kuruvilla, V.V. Bhanuprasad, K.S. Prasad, Y.R. Mahajan, Bull. Mater. Sci. 12 (1989) 495-505.

[13] E. Hornbogen, E.A. Starke, Acta Metall. Mater. 41 (1993) 1-16.

[14] J. Rosler, M. Baker, Acta Mater. 48 (2000) 3553-3567.

[15] C. Suryanarayana, N. Al-Aqeeli, Prog. Mater. Sci. 58 (2013) 383-502.

[16] S.H. Hong, Y.G. Kim, H.Y. Kim, J.M. Poole, J.J. Debarbadillo, in: R. Darolia, J.J. Lewandowski, C.T. Liu, P.L. Martin, D.B. Miracle, M.V. Nathal (Eds.), Proceeding of the 2nd International Conference on Structural Applications of Mechanical Alloying, Vancouver, British Columbia, 1993, p. 69.

[17] K.N. Allahar, J. Burns, B. Jaques, Y. Wu, I. Charit, J.I. Cole, D.P. Butt, J. Nucl. Mater. 443 (2013) 256-265.

[18] A.Z. Munir, U. Anselmi-Tamburini, M. Ohyanagi, J. Mater. Sci. 41 (2006) 763-777.

[19] M.J. Alinger, R.G. Odette, G.E. Lucas, J. Nucl. Mater. 307 (2002) 484-489.

[20] S. Kandukuri, Met. Powder Rep. 63 (2008) 22-27.

[21] H. Ke, L.X. Qiang, Y. Chao, L.Y. Yuan, Trans. Nonferrous Met. Soc. China 21 (2011) 493-501. 
[22] J.R. Groza and A. Zavaliangos, Mater. Sci. Eng. A, 287 (2000) 171-177.

[23] S. Pasebani, A.K. Dutt, I. Charit, R.S. Mishra, Mater. Sci. Forum 783-786 (2014) 1099-1104.

[24] M. Nanko, M. Sato, K. Matsumaru, K. Ishikazi, Mater. Sci. Forum 510-511 (2006) 818-821.

[25] B.I. Lopez, E.M. Fracnco, H. Zoz, L.G. Trapaga-Martinez, Revista Mexican De Fisica 57 (2011) 176-183.

[26] C. Dong, J. Appl. Cryst. 32 (1999) 838.

[27] J.B. Nelson, D.P. Riley, Proc. Phys. Soc. 57 (1945) 160-177.

[28] G.K. Williamson, W.H. Hall, Acta Metall. 1 (1953) 22-31.

[29] D. Horton, C.B. Thomson, V. Randle, Mater. Sci. Eng. A 203 (1995) 408-414.

[30] V. Randle, P.R. Rios, Y. Hu, Scripta Mater. 58 (2008) 130-133.

[31] V. Randle, The Role of the Coincident Site Lattice in Grain Boundary Engineering, The Institute of Materials, London, 1996.

[32] B. Srinivasarao, K. Ohishi, T. Ohkubo, K. Hono, Acta Mater. 57 (2009) 3277-3286.

[33] S. Pasebani, I. Charit, J. Alloys Compds. 599 (2014) 206-211.

[34] S.L. Shang, C.L. Zacherl, Y. Fang, Y. Du, Z.K. Liu, J. Phys: Condens. Matter 24 (2012) 505403.

[35] H. Wen, E.J. Lavernia, Scripta Mater. 67 (2012) 245-248.

[36] M. Nganbe, M. Heilmaier, Mater. Sci. Eng. A 387-389 (2004) 609-612.

[37] L. Hsiung, M. Fluss, S. Tumey, J. Kuntz, B. El-Dasher, M. Wall, B. Choi, A. Kimura, F. Willaime, Y. Serruys, J. Nucl. Mater. 409 (2011) 72-79.

[38] M.K. Miller, D.T. Hoelzer, E.A. Kenik, K.F. Russell, J. Nucl. Mater. 329-333 (2004) 338-341.

[39] W. Gale, T. Totemeier, Smithells Metals Reference Book, Elsevier, Amsterdam, 2004.

[40] S. Pasebani, I. Charit, Y.Q. Wu, D.P. Butt, J.I. Cole, Acta Mater. 61 (2013) 5605-5617.

[41] L. Farbaniec, G. Dirras, A. Krawczynska, F. Mompiou, H. Couque, F. Naimi, F. Bernard, D. Tingaud, Mater. Charact. 2014;doi.org/10.1016/j.matchar.2014.05.008.

[42] J.L. Bair, S.L. Hatch, D.P. Field, Scripta Mater.81 (2014) 52-55.

[43] S. Fang, W. Chen, Z. Fu, Mater. Design 54 (2014) 973-979.

[44] C.B. Thomson, V R. Scripta Mater. 35 (1996) 385-390.

[45] E. Hornbogen, P. Haasen, V. Gerold, G. Kostorz, Gupt S., Proceedings of ICAPP '06 of the 5th International Conference, Pergamon Press, Aachen, Germany, 1979, p.137.

[46] D.M. Norfleet, D.M. Dimiduk, S.J. Polasik, M.D. Uchic, M.J. Mills, Acta Mater. 56 (2008) 29883001 .

[47] L.A. Gypen, A. Deruyttere, J. Mater. Sci. 12 (1977) 1034-1038.

[48] A. Roth, C.L. Davis, R.C. Thomson, Metall. Mater. Trans. A 28 (1997) 1329-1335.

[49] J.E. Bailey, P.B. Hirsch, Philos. Mag. 5 (1960) 485-497.

[50] K. Nakashima, M. Suzuki, Y. Futamura, T. Tsuchiyama, S. Takaki, Mater. Sci. Forum 503-504 (2006) 627-632.

[51] T.M. Pollock, T. Sammy, J. Propul. Power 22 (2006) 361-374.

[52] Q.H. Bui, S. Dirras, G. Ramtani, R. Gubicza, Mater. Sci. Eng. A 527(2010) 3227-3235.

[53] L.M. Brown, R.K. Ham, in: A. Kelly, R.B. Nicholson (eds.), Strengthening Methods in Crystals, Elsevier, Amsterdam, 1971, 9-135.

[54] T.A. Parthasarathy, S.I. Rao, D.M. Dimiduk, Superalloys, TMS, 2004.

[55] N. Chawla, Y. Chen, Adv. Eng. Mater. 3 (2001) 357-370.

[56] C. Suryanarayana, Prog. Mater. Sci. 46 (2001) 1-184. 

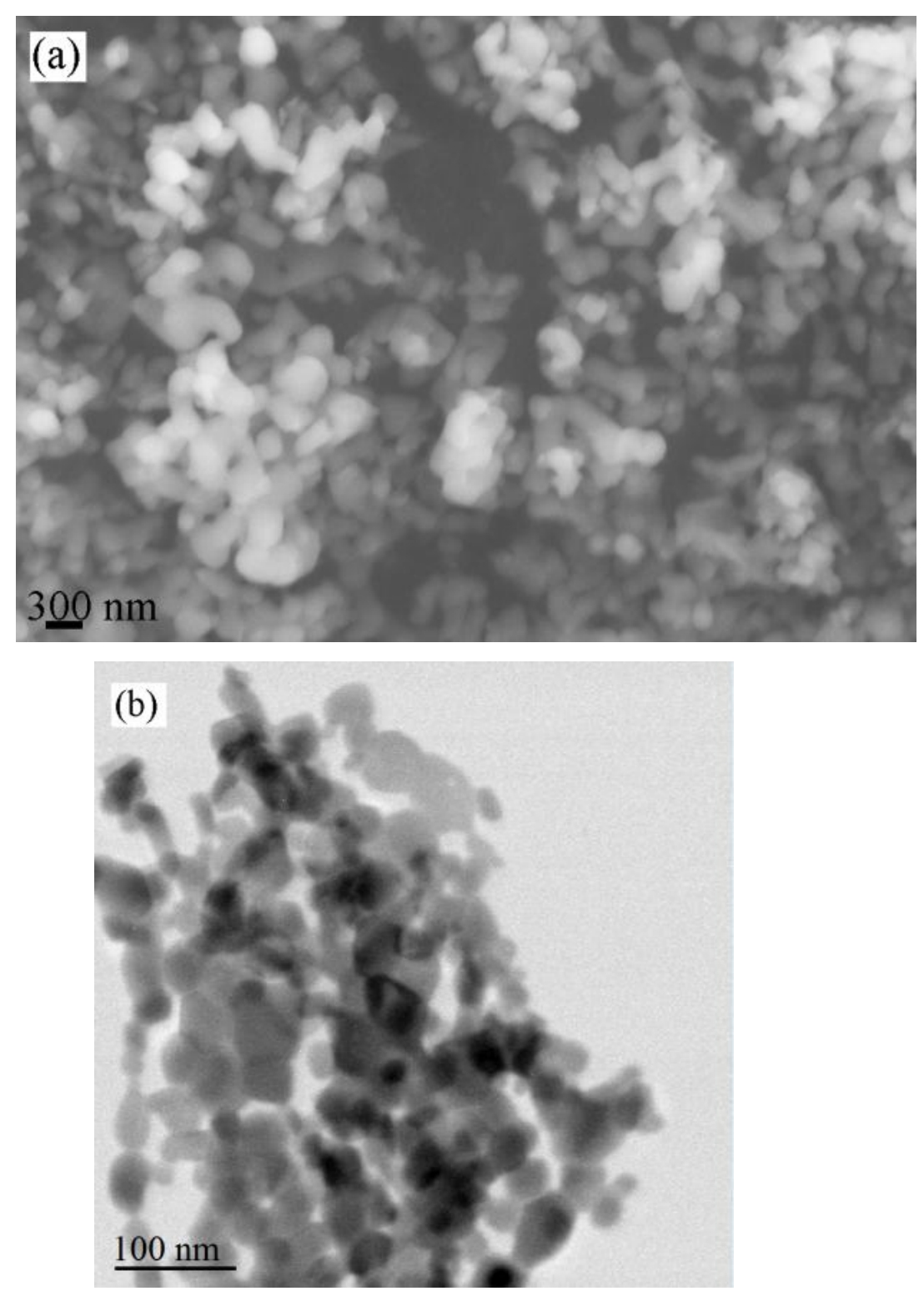

Fig. 1. (a) A SEM micrograph of the as received $\mathrm{Al}_{2} \mathrm{O}_{3}$ powder, and (b) a HAADF STEM micrograph of the $\mathrm{Y}_{2} \mathrm{O}_{3}$ powder
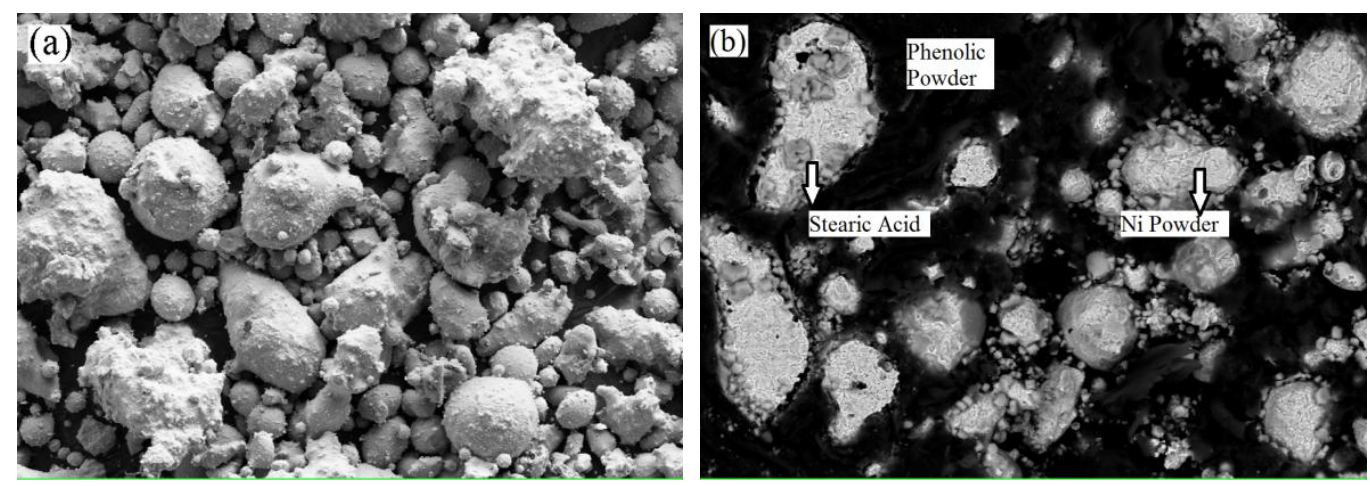

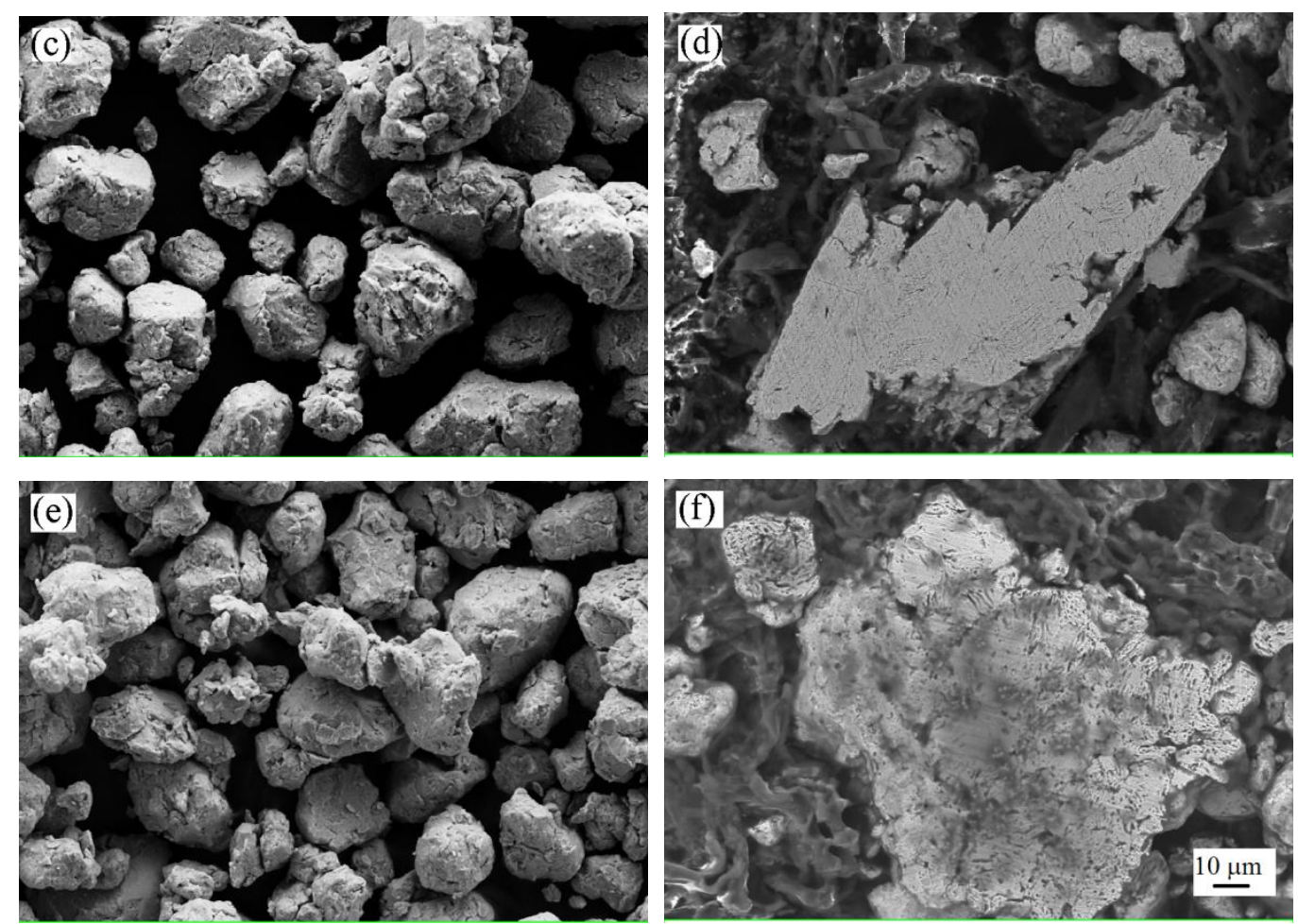

Fig. 2. SEM micrographs of $\mathrm{Ni}-20 \mathrm{Cr}-1.2 \mathrm{Y}_{2} \mathrm{O}_{3}$ (1 wt. \% stearic acid): (a) powder morphology after 0 $\mathrm{h}$ milling, (b) cross sectional observation after $0 \mathrm{~h}$ milling, (c) powder morphology after $2 \mathrm{~h}$ milling,

(d) cross sectional observation after $2 \mathrm{~h}$ milling, (e) powder morphology after $4 \mathrm{~h}$ milling and (f) cross sectional observation after $4 \mathrm{~h}$ milling 


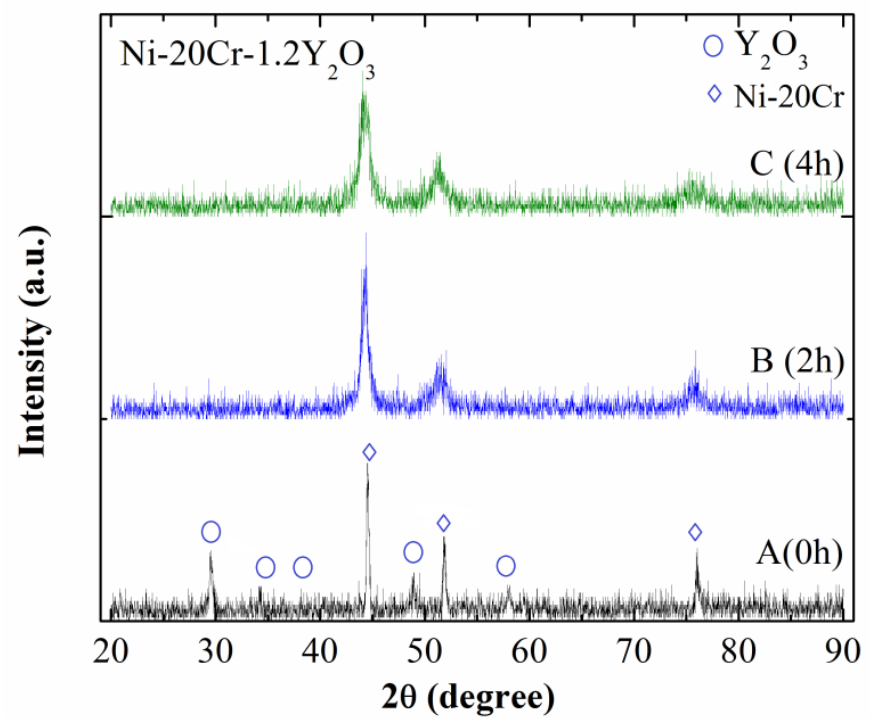

Fig. 3. XRD patterns of Ni-20Cr-1.2 $\mathrm{Y}_{2} \mathrm{O}_{3}$ alloys milled for $0 \mathrm{~h}$ (alloy A), $2 \mathrm{~h}$ (alloy B) and $4 \mathrm{~h}$ (alloy C)

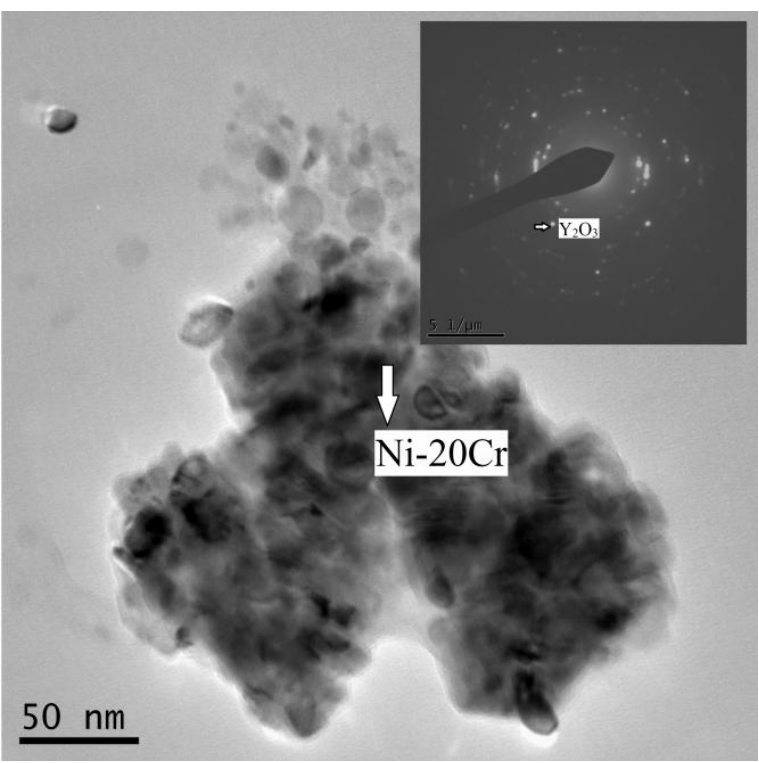


Fig. 4. Microstructure of $\mathrm{Ni}-20 \mathrm{Cr}-1.2 \mathrm{Y}_{2} \mathrm{O}_{3}$ powder milled for $2 \mathrm{~h}$ (alloy $\mathrm{B}$ ) and the corresponding diffraction pattern
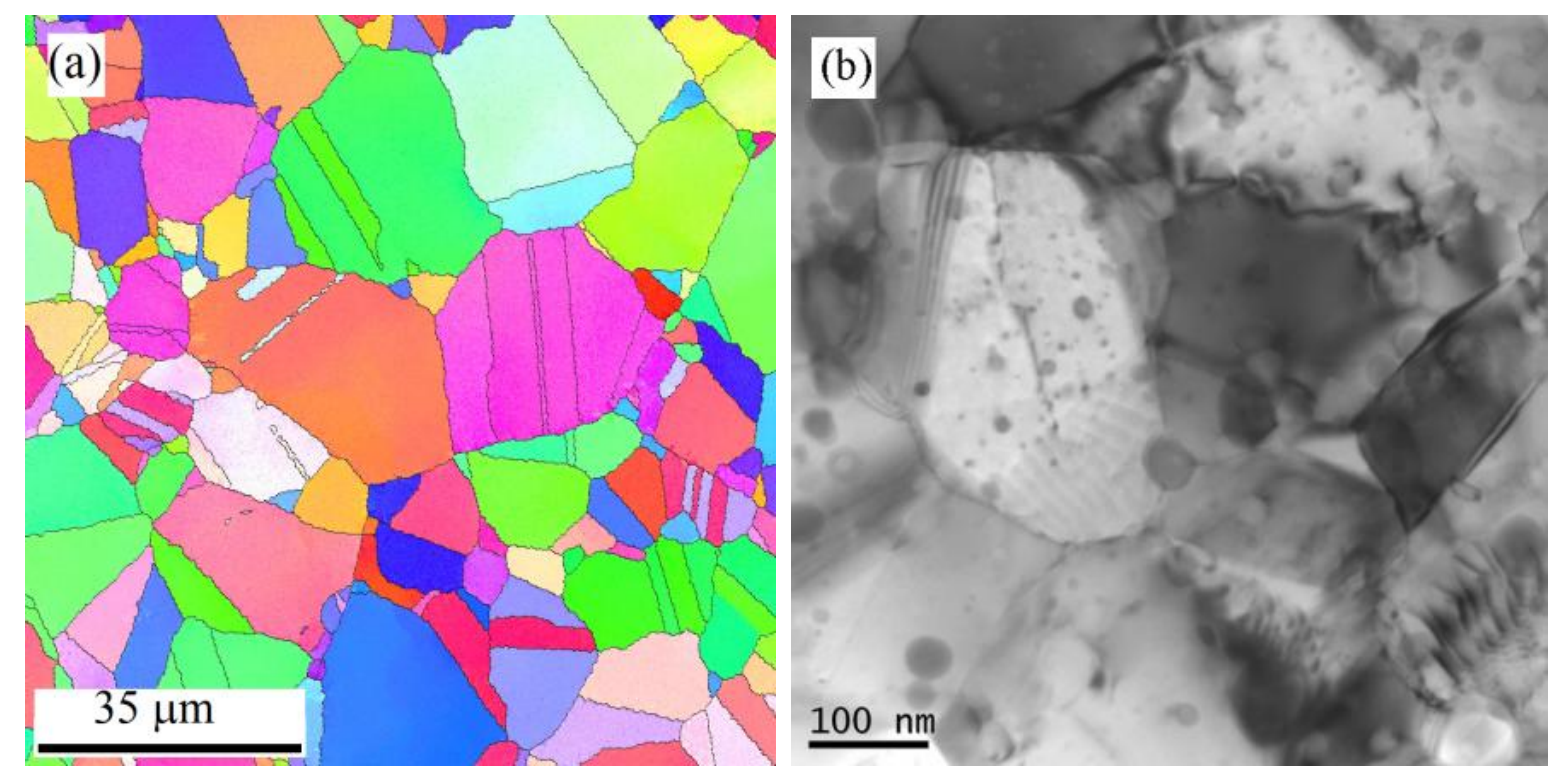

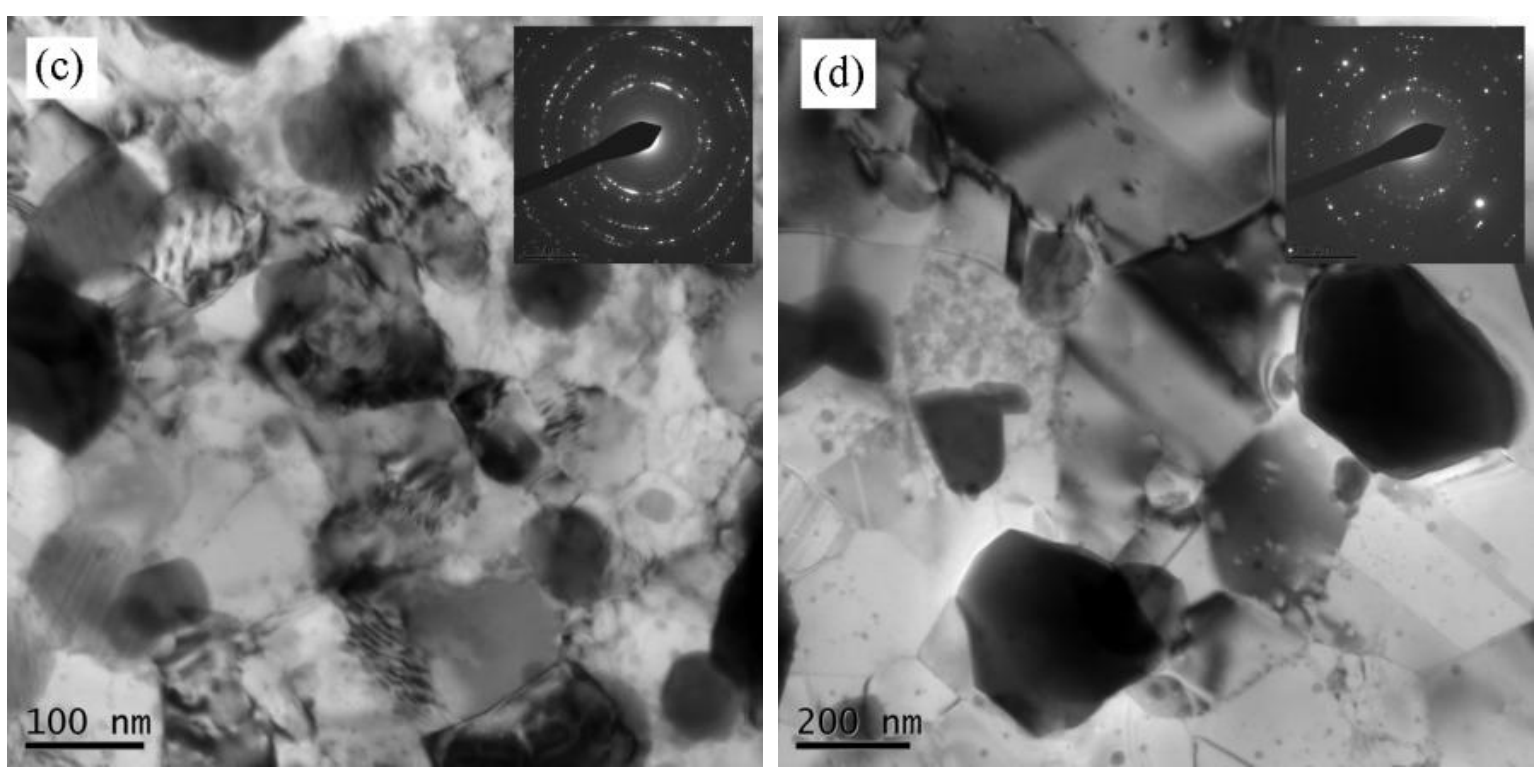

Fig. 5. The micrographs of Ni-20Cr-1.2 $\mathrm{Y}_{2} \mathrm{O}_{3}$ alloy milled for (a) $0 \mathrm{~h}$ (alloy A), (b) $2 \mathrm{~h}$ (alloy B), (c) $4 \mathrm{~h}$ (alloy C) showing nanograins and (d) $4 \mathrm{~h}$ (alloy C) showing coarse grains 

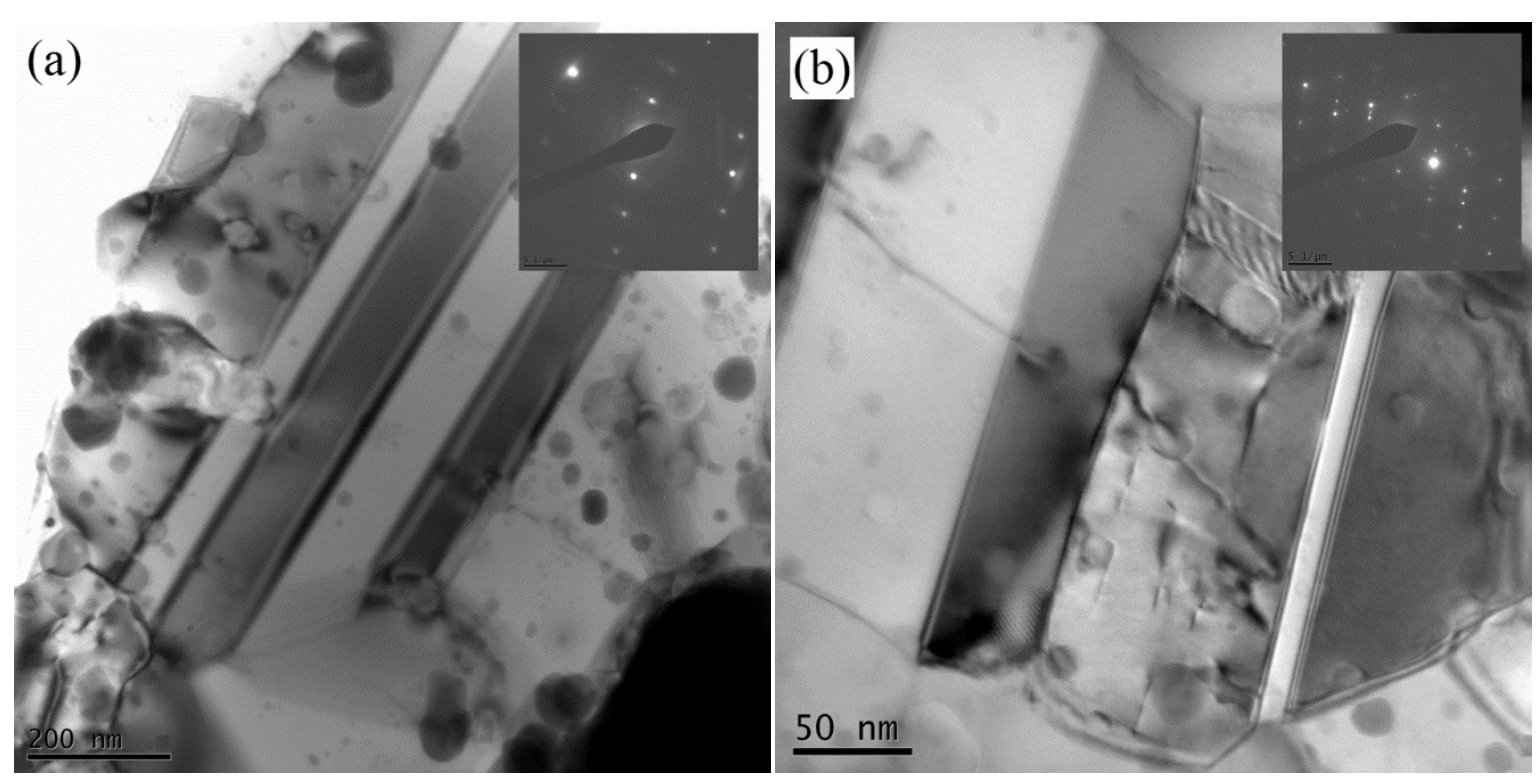

Fig. 6. Twins in the microstructure of Ni-20Cr-1.2 $\mathrm{Y}_{2} \mathrm{O}_{3}$ alloy milled for (a) $2 \mathrm{~h}$ (alloy B) and (b) $4 \mathrm{~h}$ (alloy C) 


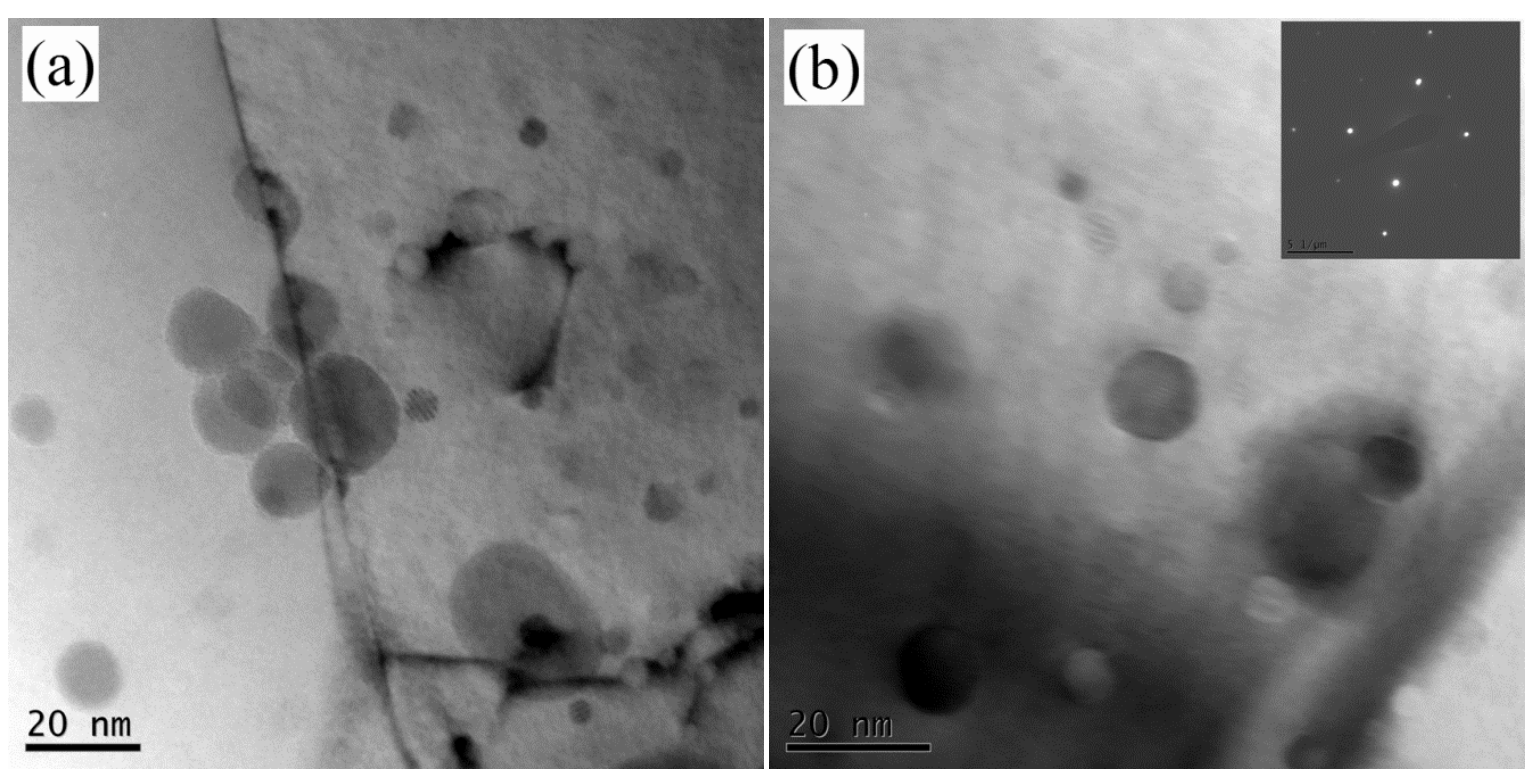

Fig. 7. The oxide dispersoid in the microstructure of the SPSed Ni-20Cr- $1.2 \mathrm{Y}_{2} \mathrm{O}_{3}$ alloys milled for (a) $2 \mathrm{~h}$ (alloy B) and (b) $4 \mathrm{~h}$ (alloy C) 

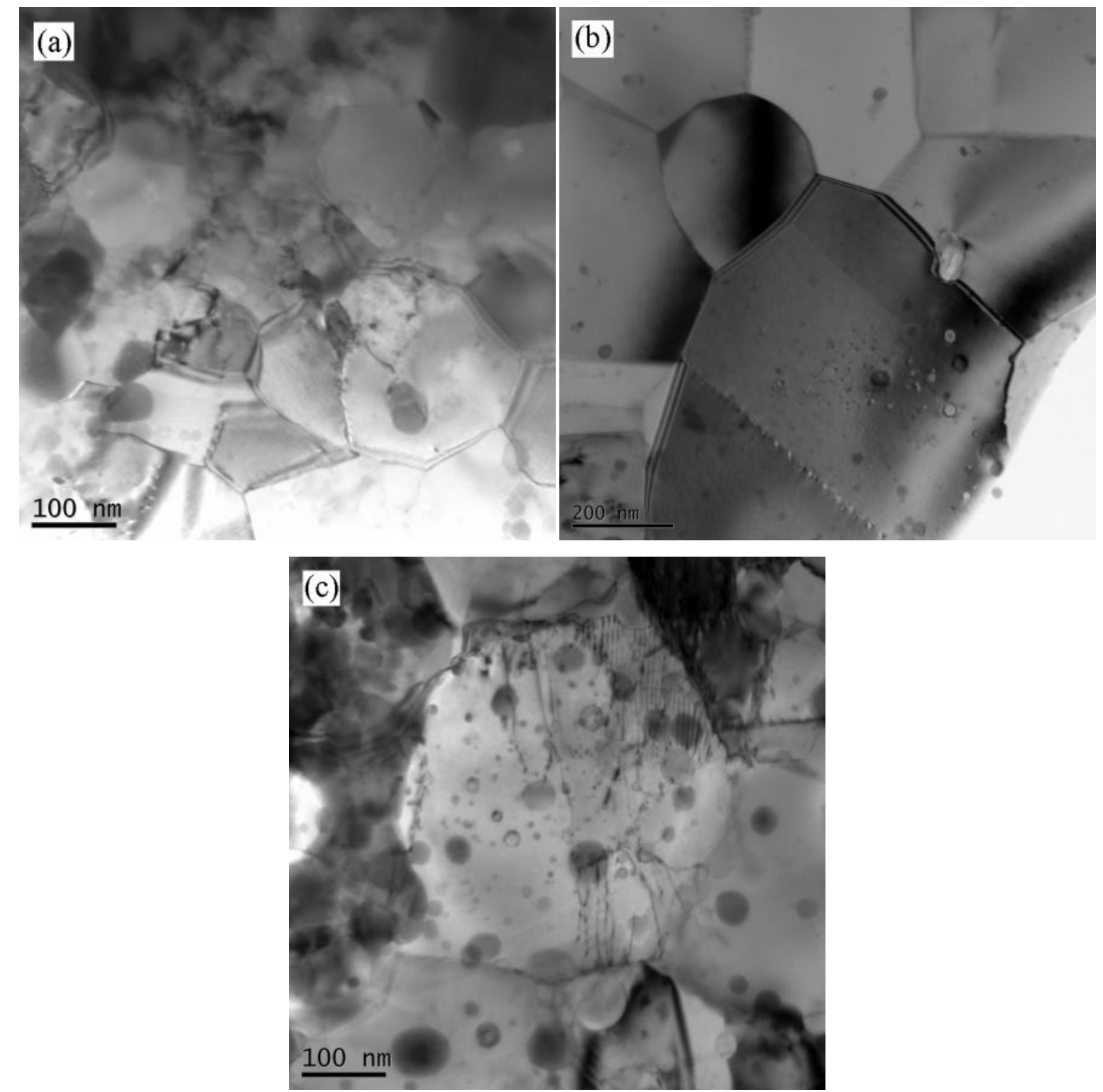

Fig. 8. The microstructure of Ni-20Cr-1.2 $\mathrm{Y}_{2} \mathrm{O}_{3}$ alloy sintered at (a) $900{ }^{\circ} \mathrm{C}$ for 5 min (alloy E), (b) $1100{ }^{\circ} \mathrm{C}$ for $5 \mathrm{~min}$ (alloy G) and (c) $1100{ }^{\circ} \mathrm{C}$ for $30 \mathrm{~min}$ (alloy B) 

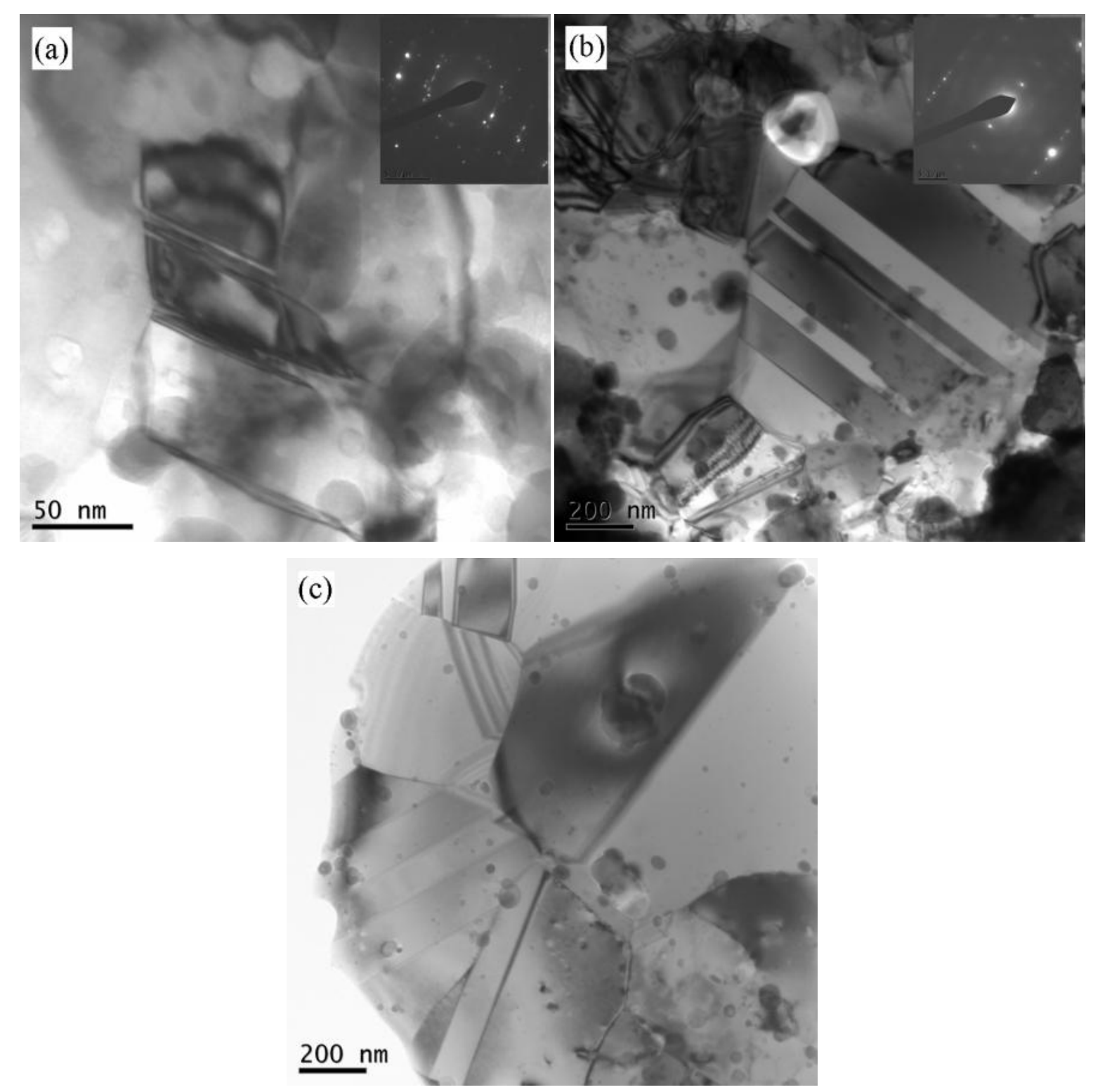

Fig. 9. Twins in the microstructure of Ni-20Cr- $1.2 \mathrm{Y}_{2} \mathrm{O}_{3}$ alloys sintered at (a) $900{ }^{\circ} \mathrm{C}$ for $5 \mathrm{~min}$ (alloy E), (b) $1100{ }^{\circ} \mathrm{C}$ for $5 \mathrm{~min}$ (alloy G) and (c) $1100{ }^{\circ} \mathrm{C}$ for $30 \mathrm{~min}$ (alloy B) 

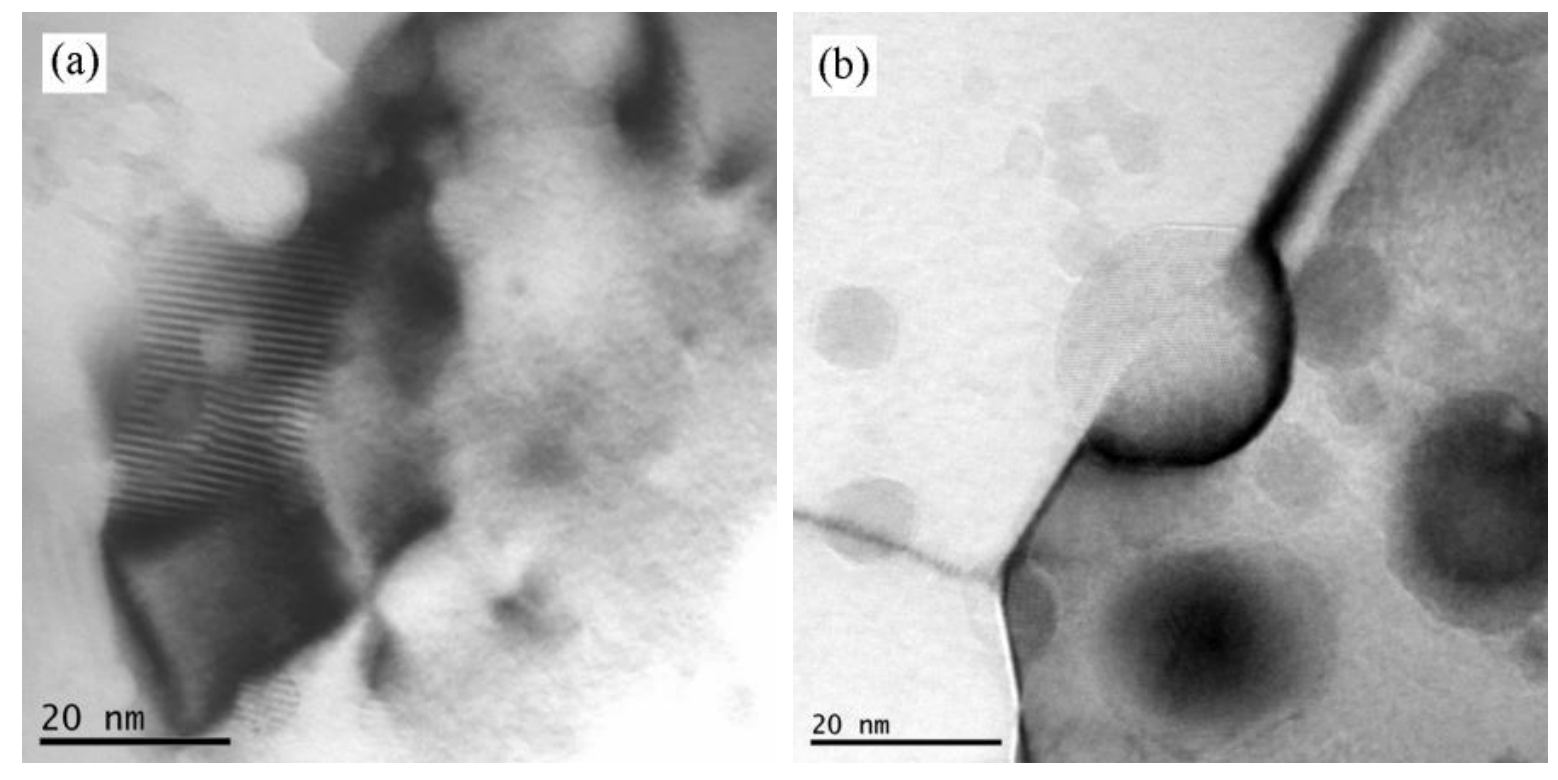

Fig. 10. The oxide dispersoid in the microstructure of $\mathrm{Ni}-20 \mathrm{Cr}-1.2 \mathrm{Y}_{2} \mathrm{O}_{3}$ alloy sintered at (a) 900 ${ }^{\circ} \mathrm{C}$ for $5 \mathrm{~min}$ (alloy E), (b) $1100{ }^{\circ} \mathrm{C}$ for $5 \mathrm{~min}$ (alloy G) 

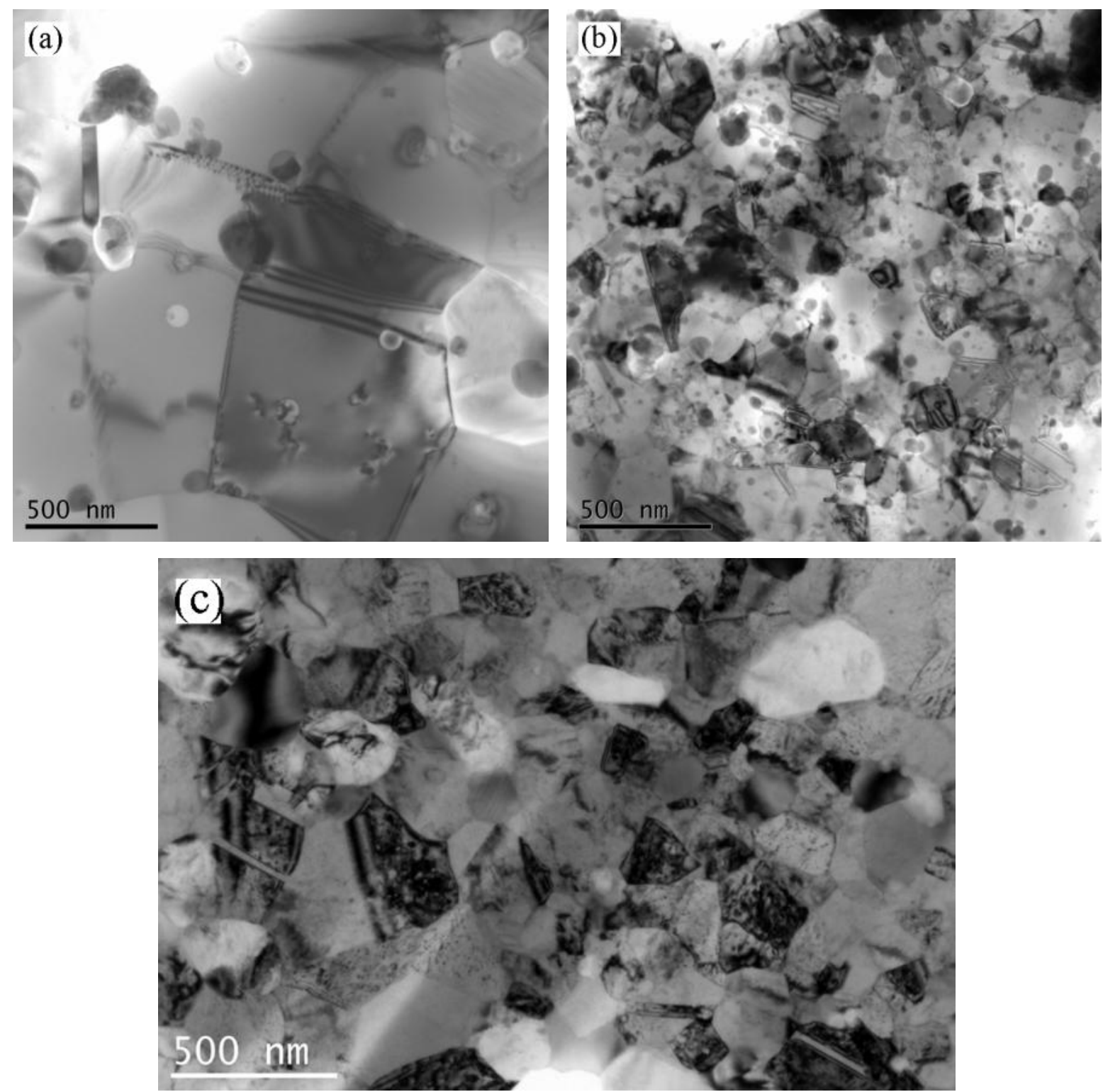

Fig. 11. The TEM micrographs of alloys with different compositions; (a) Ni-20Cr (alloy H), (b) Ni$20 \mathrm{Cr}-1.2 \mathrm{Y}_{2} \mathrm{O}_{3}$ (alloy B) and (c) Ni-20Cr- $1.2 \mathrm{Y}_{2} \mathrm{O}_{3}-5 \mathrm{Al}_{2} \mathrm{O}_{3}$ (alloy I) 

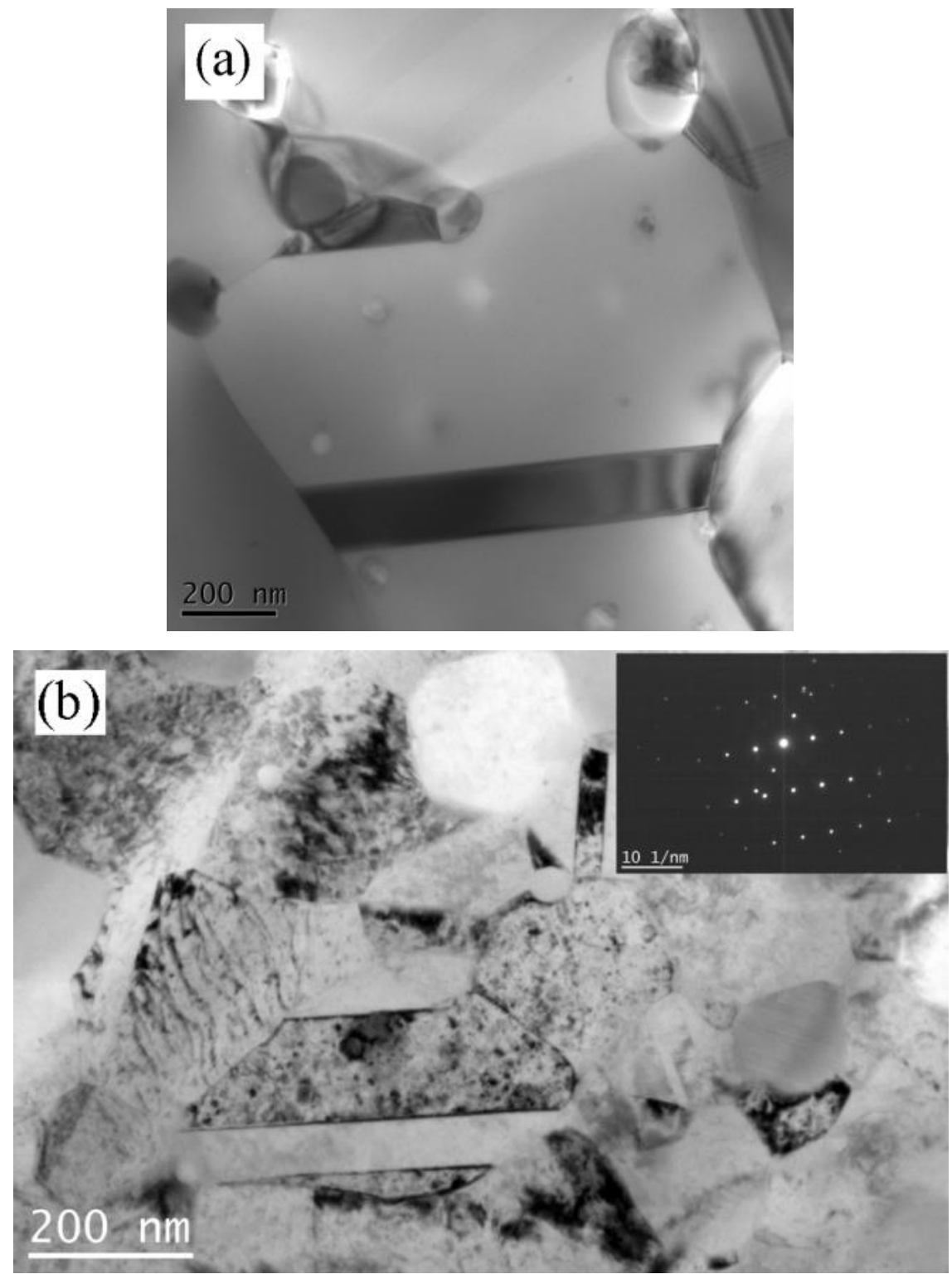

Fig. 12. Twins in the microstructure of alloys with different compositions;

(a) $\mathrm{Ni}-20 \mathrm{Cr}$ (alloy $\mathrm{H}$ ) and (b) $\mathrm{Ni}-20 \mathrm{Cr}-1.2 \mathrm{Y}_{2} \mathrm{O}_{3}-5 \mathrm{Al}_{2} \mathrm{O}_{3}$ (alloy I) (twinning in alloy $\mathrm{B}$ is previously shown in Fig. 6a) 

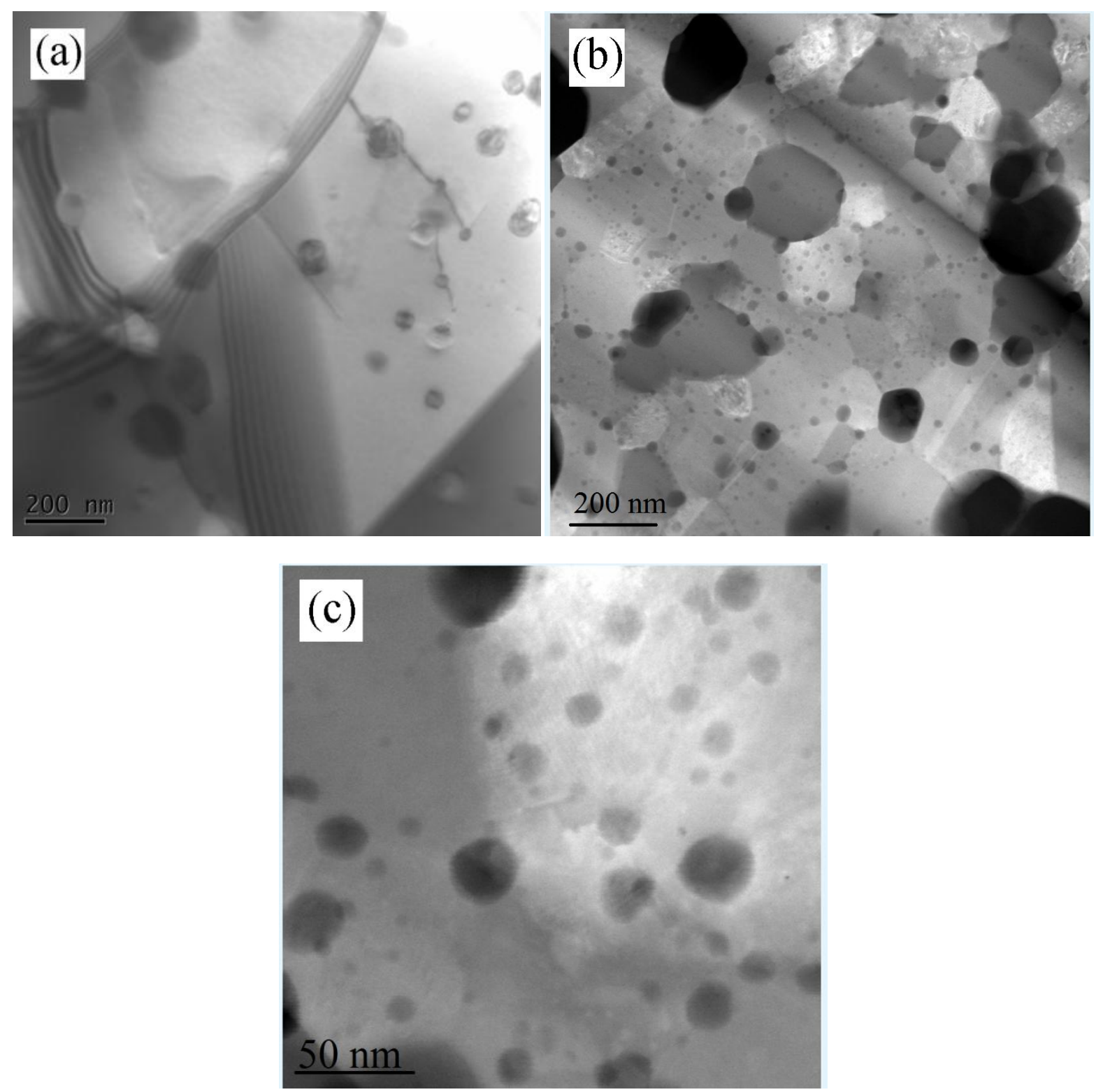

Fig. 13. The oxide dispersoid with different compositions: (a) a BF TEM micrograph of alloy H, (b) HAADF STEM micrograph obtained from alloy I and (c) higher magnification micrograph of alloy H 

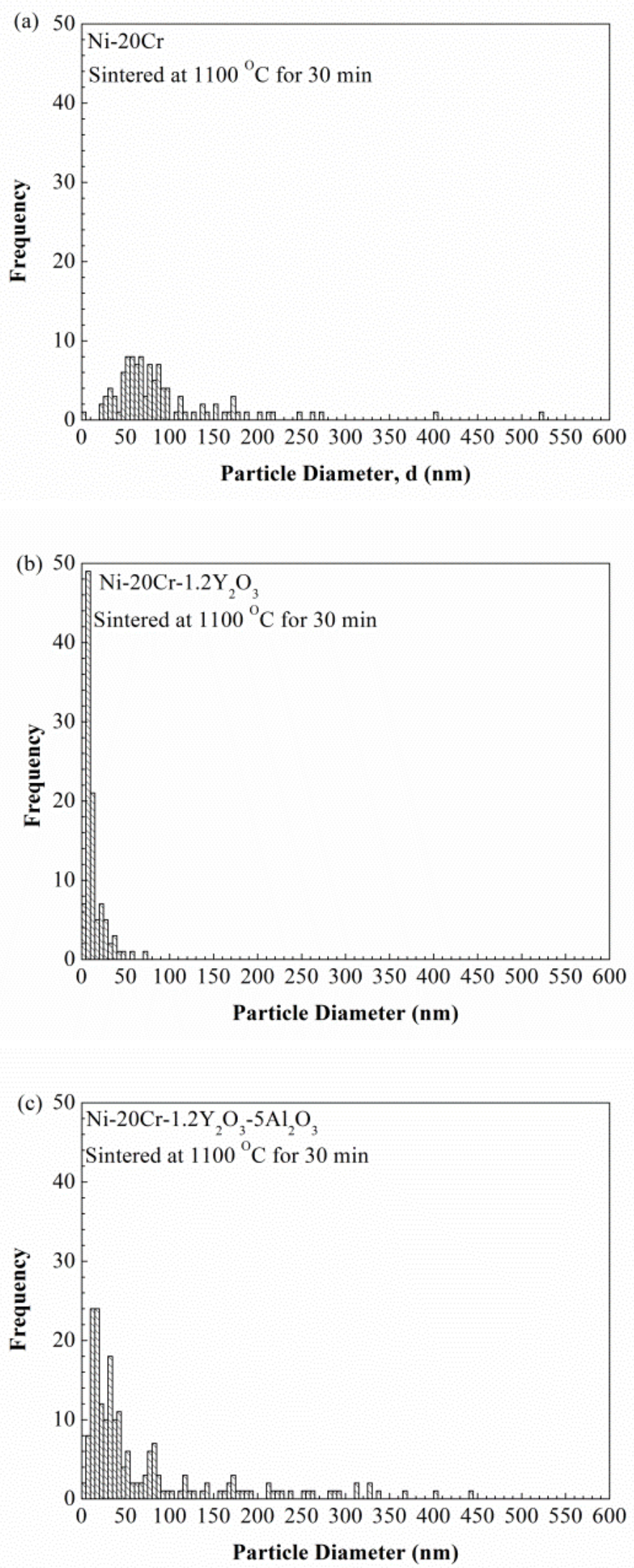

Fig. 14. Particle size distribution of alloys with different compositions; (a) alloy H, (b) alloy B and (c) alloy I (approximately 500 particles were counted for each plot) 


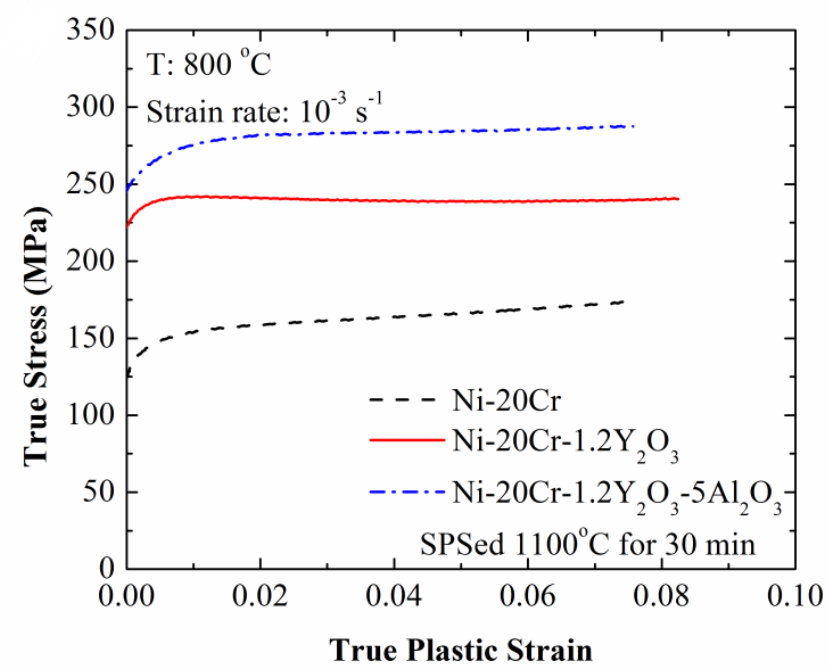

Fig. 15. True stress-true plastic strain curves obtained at $800{ }^{\circ} \mathrm{C}$ for $\mathrm{Ni}-20 \mathrm{Cr}, \mathrm{Ni}-20 \mathrm{Cr}-1.2 \mathrm{Y}_{2} \mathrm{O}_{3}$ and $\mathrm{Ni}-20 \mathrm{Cr}-1.2 \mathrm{Y}_{2} \mathrm{O}_{3}-5 \mathrm{Al}_{2} \mathrm{O}_{3}$ alloys sintered at $1100{ }^{\circ} \mathrm{C}$ for $30 \mathrm{~min}$ 


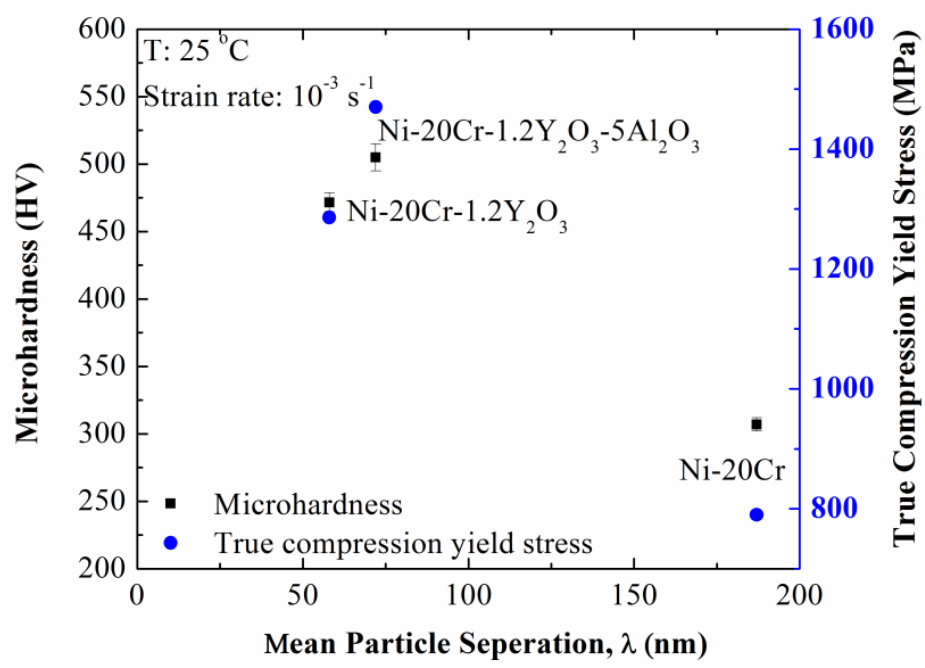

Fig. 16. The variation of microhardness and true compression yield strength values (at room temperature) as a function of mean particle separation $(\lambda)$. 
Table 1. Different milling time, SPS temperatures, SPS dwell times and alloy compositions altered in processing Ni-

based ODS alloys considered for current study

\begin{tabular}{|c|c|c|c|c|}
\hline & Alloy (wt.\%) & $\begin{array}{l}\text { Milling Time } \\
\text { (h) }\end{array}$ & SPS Parameters & Alloy Code \\
\hline Effect of Milling & $\mathrm{Ni}-20 \mathrm{Cr}-1.2 \mathrm{Y}_{2} \mathrm{O}_{3}$ & 0 & $1100{ }^{\circ} \mathrm{C} / 30 \mathrm{~min}$ & $\mathrm{~A}$ \\
\hline \multirow[t]{2}{*}{ Time } & $\mathrm{Ni}-20 \mathrm{Cr}-1.2 \mathrm{Y}_{2} \mathrm{O}_{3}$ & 2 & $1100{ }^{\circ} \mathrm{C} / 30 \mathrm{~min}$ & B \\
\hline & $\mathrm{Ni}-20 \mathrm{Cr}-1.2 \mathrm{Y}_{2} \mathrm{O}_{3}$ & 4 & $1100^{\circ} \mathrm{C} / 30 \mathrm{~min}$ & $\mathrm{C}$ \\
\hline Effect of SPS & $\mathrm{Ni}-20 \mathrm{Cr}-1.2 \mathrm{Y}_{2} \mathrm{O}_{3}$ & 2 & $600{ }^{\circ} \mathrm{C} / 5 \mathrm{~min}$ & $\mathrm{D}$ \\
\hline \multirow[t]{4}{*}{ Parameters } & $\mathrm{Ni}-20 \mathrm{Cr}-1.2 \mathrm{Y}_{2} \mathrm{O}_{3}$ & 2 & $900{ }^{\circ} \mathrm{C} / 5 \mathrm{~min}$ & $\mathrm{E}$ \\
\hline & $\mathrm{Ni}-20 \mathrm{Cr}-1.2 \mathrm{Y}_{2} \mathrm{O}_{3}$ & 2 & $1000{ }^{\circ} \mathrm{C} / 5 \mathrm{~min}$ & $\mathrm{~F}$ \\
\hline & $\mathrm{Ni}-20 \mathrm{Cr}-1.2 \mathrm{Y}_{2} \mathrm{O}_{3}$ & 2 & $1100{ }^{\circ} \mathrm{C} / 5 \mathrm{~min}$ & $\mathrm{G}$ \\
\hline & $\mathrm{Ni}-20 \mathrm{Cr}-1.2 \mathrm{Y}_{2} \mathrm{O}_{3}$ & 2 & $1100{ }^{\circ} \mathrm{C} / 30 \mathrm{~min}$ & $\mathrm{~B}$ \\
\hline Effect of Alloy & $\mathrm{Ni}-20 \mathrm{Cr}$ & 2 & $1100{ }^{\circ} \mathrm{C} / 30 \mathrm{~min}$ & $\mathrm{H}$ \\
\hline \multirow[t]{2}{*}{ Composition } & $\mathrm{Ni}-20 \mathrm{Cr}-1.2 \mathrm{Y}_{2} \mathrm{O}_{3}$ & 2 & $1100^{\circ} \mathrm{C} / 30 \mathrm{~min}$ & B \\
\hline & $\mathrm{Ni}-20 \mathrm{Cr}-1.2 \mathrm{Y}_{2} \mathrm{O}_{3}-5 \mathrm{Al}_{2} \mathrm{O}_{3}$ & 2.5 & $1100{ }^{\circ} \mathrm{C} / 30 \mathrm{~min}$ & I \\
\hline
\end{tabular}

Table 2. Microstructural parameters of $\mathrm{Ni}-20 \mathrm{Cr}-1.2 \mathrm{Y}_{2} \mathrm{O}_{3}$ powder milled for $0 \mathrm{~h}, 2 \mathrm{~h}$ and $4 \mathrm{~h}$ as determined by XRD

\begin{tabular}{cccc}
\hline $\begin{array}{c}\text { Milling Time } \\
(\mathrm{h})\end{array}$ & $\begin{array}{c}\text { Crystallite Size } \\
(\mathrm{nm})\end{array}$ & $\begin{array}{c}\text { Lattice Strain } \\
(\%)\end{array}$ & $\begin{array}{c}\text { Lattice Constant } \\
(\mathrm{nm})\end{array}$ \\
\hline 0 & $44 \pm 12$ & $0.03 \pm 0.001$ & $0.3530 \pm 0.0002$ \\
2 & $14 \pm 7$ & $0.03 \pm 0.001$ & $0.3536 \pm 0.0003$ \\
4 & $4 \pm 2$ & $0.15 \pm 0.003$ & $0.3560 \pm 0.0004$ \\
\hline
\end{tabular}

Table 3. Physical density, relative density and microhardness values using different milling times; for alloys A, B and C

\begin{tabular}{|c|c|c|c|}
\hline Alloy & $\begin{array}{l}\text { Physical Density } \\
\qquad\left(\mathrm{g} / \mathrm{cm}^{3}\right)\end{array}$ & $\begin{array}{c}\text { Relative Density } \\
(\%)\end{array}$ & $\begin{array}{c}\text { Microhardness } \\
\text { (HV) }\end{array}$ \\
\hline $\mathrm{A}(0 \mathrm{~h})$ & $8.228 \pm 0.005$ & $\sim 100$ & $202 \pm 6$ \\
\hline B $(2 \mathrm{~h})$ & $8.170 \pm 0.008$ & $99.55 \pm 0.10$ & $472 \pm 7$ \\
\hline $\mathrm{C}(4 \mathrm{~h})$ & $8.226 \pm 0.005$ & $\sim 100$ & $527 \pm 21$ \\
\hline
\end{tabular}


Table 4. Physical density, relative density and microhardness values of $\mathrm{Ni}-20 \mathrm{Cr}-1.2 \mathrm{Y}_{2} \mathrm{O}_{3}$ alloys sintered at different temperatures and times; for alloys D, E, F, G and B

\begin{tabular}{lccc}
\hline Alloy & $\begin{array}{c}\text { Physical Density } \\
\left(\mathrm{g} / \mathrm{cm}^{3}\right)\end{array}$ & $\begin{array}{c}\text { Relative Density } \\
(\%)\end{array}$ & $\begin{array}{c}\text { Microhardness } \\
(\mathrm{HV})\end{array}$ \\
\hline $\mathrm{D}\left(600^{\circ} \mathrm{C}\right.$ for $\left.5 \mathrm{~min}\right)$ & $5.924 \pm 0.020$ & $72.18 \pm 0.24$ & $131 \pm 31$ \\
$\mathrm{E}\left(900^{\circ} \mathrm{C}\right.$ for $\left.5 \mathrm{~min}\right)$ & $7.708 \pm 0.002$ & $93.93 \pm 0.02$ & $395 \pm 11$ \\
$\mathrm{~F}\left(1000^{\circ} \mathrm{C}\right.$ for $\left.5 \mathrm{~min}\right)$ & $8.150 \pm 0.030$ & $99.26 \pm 0.30$ & $556 \pm 4$ \\
$\mathrm{G}\left(1100^{\circ} \mathrm{C}\right.$ for $\left.5 \mathrm{~min}\right)$ & $8.163 \pm 0.004$ & $99.48 \pm 0.04$ & $470 \pm 7$ \\
$\mathrm{~B}\left(1100^{\circ} \mathrm{C}\right.$ for $\left.30 \mathrm{~min}\right)$ & $8.170 \pm 0.008$ & $99.55 \pm 0.10$ & $472 \pm 7$ \\
\hline
\end{tabular}

Table 5. Physical density, relative density and microhardness values using different alloying composition; for alloys H, $\mathrm{B}$ and I

\begin{tabular}{lccc}
\hline Alloy & $\begin{array}{c}\text { Physical Density } \\
\left(\mathrm{g} / \mathrm{cm}^{3}\right)\end{array}$ & $\begin{array}{c}\text { Relative Density } \\
(\%)\end{array}$ & $\begin{array}{c}\text { Microhardness } \\
(\mathrm{HV})\end{array}$ \\
\hline $\mathrm{H}(\mathrm{Ni}-20 \mathrm{Cr})$ & $8.19 \pm 0.01$ & $98.95 \pm 0.03$ & $307 \pm 3$ \\
$\mathrm{~B}\left(\mathrm{Ni}-20 \mathrm{Cr}-1.2 \mathrm{Y}_{2} \mathrm{O}_{3}\right)$ & $8.17 \pm 0.01$ & $99.55 \pm 0.04$ & $472 \pm 7$ \\
$\mathrm{I}\left(\mathrm{Ni}-20 \mathrm{Cr}-1.2 \mathrm{Y}_{2} \mathrm{O}_{3}-5 \mathrm{Al}_{2} \mathrm{O}_{3}\right)$ & $7.70 \pm 0.01$ & $99.18 \pm 0.02$ & $505 \pm 10$ \\
\hline
\end{tabular}

Table 6. The compression yield stress values of $\mathrm{Ni}-20 \mathrm{Cr}$, Ni20-Cr- $1.2 \mathrm{Y}_{2} \mathrm{O}_{3}$ and $\mathrm{Ni}-20 \mathrm{Cr}-1.2 \mathrm{Y}_{2} \mathrm{O}_{3}-5 \mathrm{Al}_{2} \mathrm{O}_{3}$ alloys sintered at $1100{ }^{\circ} \mathrm{C}$ for $30 \mathrm{~min}$

\begin{tabular}{lcc}
\hline Alloy & $\begin{array}{c}\text { Compression Yield } \\
\text { Stress at } 25{ }^{\circ} \mathrm{C}(\mathrm{MPa})\end{array}$ & $\begin{array}{c}\text { Compression Yield } \\
\text { Stress at } 800{ }^{\circ} \mathrm{C}(\mathrm{MPa})\end{array}$ \\
\hline $\mathrm{H}(\mathrm{Ni}-20 \mathrm{Cr})$ & 790 & 125 \\
$\mathrm{~B}\left(\mathrm{Ni}-20 \mathrm{Cr}-1.2 \mathrm{Y}_{2} \mathrm{O}_{3}\right)$ & 1286 & 225 \\
$\mathrm{I}\left(\mathrm{Ni} 20-\mathrm{Cr}-1.2 \mathrm{Y}_{2} \mathrm{O}_{3}-5 \mathrm{Al}_{2} \mathrm{O}_{3}\right)$ & 1470 & 250 \\
\hline
\end{tabular}

Table 7. Contribution of different strengthening mechanisms in Ni-20Cr, Ni20-Cr-1.2 $\mathrm{Y}_{2} \mathrm{O}_{3}$ and Ni-20Cr-1.2 $\mathrm{Y}_{2} \mathrm{O}_{3}$ $5 \mathrm{Al}_{2} \mathrm{O}_{3}$ sintered at $1100{ }^{\circ} \mathrm{C}$ for $30 \mathrm{~min}$

\begin{tabular}{|c|c|c|c|c|c|c|c|c|}
\hline Alloy & $\begin{array}{c}\sigma_{o} \\
(\mathrm{MPa})\end{array}$ & $\begin{array}{c}\Delta \sigma_{S S} \\
(\mathrm{MPa})\end{array}$ & $\begin{array}{c}\Delta \sigma_{D} \\
(\mathrm{MPa})\end{array}$ & $\begin{array}{l}\Delta \sigma_{G B} \\
(\mathrm{MPa})\end{array}$ & $\begin{array}{l}\Delta \sigma_{\text {Oro }} \\
(\mathrm{MPa})\end{array}$ & $\begin{array}{c}\Delta \sigma_{C} \\
(\mathrm{MPa})\end{array}$ & $\begin{array}{c}\sigma_{Y} \\
\text { Calculated } \\
(\mathrm{MPa})\end{array}$ & $\begin{array}{c}\sigma_{Y} \\
\text { Experimental } \\
(\mathrm{MPa})\end{array}$ \\
\hline $\mathrm{H}(\mathrm{Ni}-20 \mathrm{Cr})$ & 8 & 158 & 68 & 257 & 295 & 0 & 786 & 790 \\
\hline $\mathrm{B}\left(\mathrm{Ni}-20 \mathrm{Cr}-1.2 \mathrm{Y}_{2} \mathrm{O}_{3}\right)$ & 8 & 158 & 96 & 359 & 650 & 0 & 1271 & 1286 \\
\hline $\mathrm{I}\left(\mathrm{Ni} 20-\mathrm{Cr}-1.2 \mathrm{Y}_{2} \mathrm{O}_{3}-5 \mathrm{Al}_{2} \mathrm{O}_{3}\right)$ & 8 & 158 & 111 & 319 & 587 & 295 & 1478 & 1470 \\
\hline
\end{tabular}

